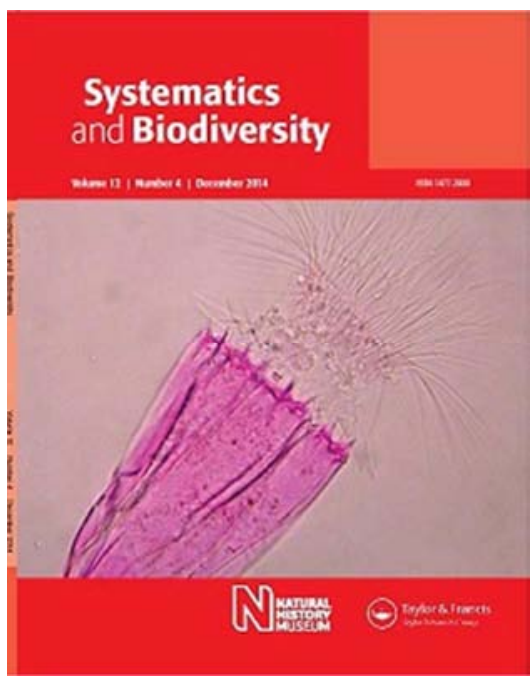

In search of phylogenetic congruence between molecular and morphological data in bryozoans with extreme adult skeletal heteromorphy

\begin{tabular}{|r|l|}
\hline Journal: & Systematics and Biodiversity \\
\hline Manuscript ID: & TSAB-2015-0002.R1 \\
\hline Manuscript Type: & Original Research Article \\
\hline Keywords: & $\begin{array}{l}\text { Bryozoa, Cyclostomata, early astogeny, molecular phylogeny, morphology, } \\
\text { New Zealand, taxonomy }\end{array}$ \\
\hline \multicolumn{2}{|l}{} \\
\hline
\end{tabular}

SCHOLARONE ${ }^{m}$

Manuscripts 


\section{In search of phylogenetic congruence between molecular and morphological data in bryozoans with extreme adult skeletal heteromorphy}

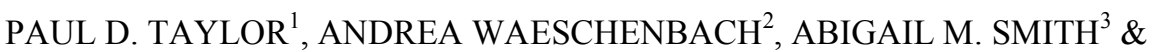
DENNIS P. GORDON ${ }^{4}$

${ }^{1}$ Department of Earth Sciences, Natural History Museum, London SW7 5BD

${ }^{2}$ Department of Life Sciences, Natural History Museum, London SW7 5BD

${ }^{3}$ Department of Marine Science, University of Otago, Dunedin 9054, New Zealand

${ }^{4}$ NIWA, Greta Point, P.O. Box 14-901, Wellington, New Zealand

The taxonomy of cyclostome bryozoans, both Recent and fossil, is founded almost entirely on characters of the mineralized skeleton. However, the adequacy of these characters is now being questioned by molecular sequence data. In this study we construct a molecular tree using ssrDNA and lsrDNA sequences and identify a clade of New Zealand cyclostomes containing species exhibiting widely different morphologies. In particular, Diaperoecia purpurascens (Hutton), a species assigned to the suborder Tubuliporina on the basis of adult skeletal morphology, is shown to be closely related to New Zealand species assigned to Heteropora, including $H$. neozelanica Busk, which has a very different adult skeleton and is traditionally placed in the suborder Cerioporina. A new species resembling the Antarctic genus Hastingsia, ' $H$ '. whitteni sp. nov., from North Island, New Zealand, is found to belong to the same clade, despite being placed conventionally in a different family (Hastingsiidae) from both Diaperoecia (Diaperoeciidae) and Heteropora (Cerioporidae). These results challenge the utility of adult skeletal morphology in cyclostome taxonomy. In contrast to the striking dissimilarity between the adult skeletons of D. purpurascens and 'Hastingsia' whitteni compared to New Zealand species of Heteropora, morphological similarities in early colony development, as well possibly as the presence of a gizzard, corroborate the molecular interpretation of their close relationships. Greater attention should be paid in the future to early astogenetic characters in cyclostome taxonomy. 
Key words: Bryozoa, Cyclostomata, early astogeny, molecular phylogeny, morphology, New Zealand, taxonomy

\section{Introduction}

A recurrent topic of discussion in taxonomy is the reliability of morphology in interpreting phylogenetic relationships and hence in devising 'natural' classifications. Molecular sequence data provide a powerful means of accessing the efficacy of morphology for this purpose. In the ideal scenario there is a high degree of congruence between molecules and morphology, corroborating the taxonomic value of morphology. However, there are numerous instances where molecular sequence data have undermined the taxonomic value of traditional morphological characters by revealing close genetic relationships between morphologically distinct taxa (e.g. Blackwell et al., 2003; Sotiaux et al., 2009; Pérez, 2011; Bourret et al., 2012).

Bryozoa is a phylum of lophotrochozoan invertebrates, distributed globally across many aquatic habitats, and moderately diverse, comprising some 5689 living species (Bock \& Gordon, 2013). The two dominant orders of modern bryozoans Cheilostomata and Cyclostomata - are both marine and have calcareous skeletons that furnish nearly all of the characters used in their taxonomy. Not only are these skeletal characters immediately obvious in preserved material, but exactly the same characters are available to palaeontologists studying fossil cheilostomes and cyclostomes.

Indeed, a common procedure in taxonomic studies of cheilostomes and cyclostomes is to soak specimens in dilute bleach to remove all soft tissues, leaving only the calcareous skeleton for identification.

A reasonably large number of skeletal morphological characters are available for cheilostome taxonomy and molecular studies at low taxonomic levels generally show good congruence with morphology (e.g., Hughes et al., 2008; Herrera-Cubilla \& Jackson, 2014), even though morphological convergence is evident between some higher taxonomic groups (Waeschenbach et al., 2012). Cyclostomes, however, have a simpler skeletal morphology and there can be significant incongruence between molecules and morphology, as is apparent from mismatches when traditional suborders founded on skeletal morphology are mapped onto molecular trees (Waeschenbach et al., 2009; Taylor et al., 2011). 


\section{The purpose of this study is to use molecular sequence data to construct a} phylogenetic tree for cyclostome bryozoans and to focus particularly on the unexpected relationships found between some species from New Zealand. These species are revised taxonomically, based on traditional skeletal characters, and morphological apomorphies supporting the molecular phylogeny are sought. One of the commonest cyclostome bryozoans found in New Zealand waters is Diaperoecia purpurascens (Hutton, 1877) (Fig. 1). Although the generic attribution of this species has varied through time, with others placing it in Entalophora or Pustulopora, it has always been considered as belonging to suborder Tubuliporina based on skeletal morphology. We here generate ssrDNA and lsrDNA sequences for Diaperoecia purpurascens for the first time, showing that the species groups within a clade containing New Zealand material attributed to Heteropora (Fig. 2). Traditional cyclostome taxonomy places Heteropora in a different suborder - Cerioporina reflecting the striking differences in the morphology of the zooidal skeletons of Diaperoecia and Heteropora. However, our molecular findings are corroborated by a study of skeletal characters from early colony development, notably the shape and pattern of the pseudopores on the protoecium, which support a close relationship among D. purpurascens, the New Zealand species of Heteropora and a previously unnamed New Zealand species of 'Hastingsia' which molecular sequence data group with these other two cyclostomes. Our findings point to the potential taxonomic value of morphological characters seen in the early colony development of cyclostome bryozoans.

\section{Material and methods}

\section{Morphology}

The material used for this study comprises historical specimens preserved in the collections of the Natural History Museum, London (NHMUK), as well as some more recently collected material from New Zealand which is now divided between the collections of the NHMUK and the National Institute for Water and Atmospheric Research (NIWA) in Wellington, New Zealand.

SEM of skeletal morphology was undertaken using LEO 1455VP and FEI Quanta 650 ESEM scanning electron microscopes at the NHMUK. These instruments 
allowed the study of uncoated, dried and bleached specimens imaged with backscattered electrons.

\section{Molecular study}

Total genomic DNA was extracted from ethanol-preserved specimens using the DNeasy tissue kit (QIAGEN) following the manufacturer's instructions. 1srDNA was amplified in two fragments using Steno250F + Steno1800R and Steno1800F + Steno3490R (Waeschenbach et al., 2009). ssrDNA was amplified in two fragments using 18e (Hillis \& Dixon, 1991) + Stenolae600R (Waeschenbach et al. 2009) and Stenolae600F (Waeschenbach et al., 2009) + 18p (Hillis \& Dixon, 1991) (for PCR cycling conditions, primer sequences and additional sequencing primer details, see Waeschenbach et al., 2009). PCR products were purified using QIAquick PCR purification Kit (QIAGEN). Sequencing was carried out on an Applied Biosystems 3730 DNA Analyser, using Big Dye version 1.1. Sequence identity was checked using the Basic Local Alignment Search Tool (BLAST) (www.ncbi.nih.gov/BLAST/). Contigs were assembled using SEQUENCHER 4.8 (GeneCodes Corporation).

Newly generated lsrDNA and ssrDNA sequences were aligned by eye to an existing alignment, as published in the supplementary data for Waeschenbach et al. (2009; see this reference for GenBank accession numbers of published sequences used in the present study). GenBank accession numbers for data generated in this study are as follows: 1srDNA 'Hastingsia' whitteni sp. nov. (KP331437), Diaperoecia purpurascens (KP331438); ssrDNA ' $H$.' whitteni sp. nov. (KP331439), D. purpurascens (KP331440),. The data were partitioned into three character sets: (1) lsrDNA, (2) ssrDNA, and (3) 1sr+ssrDNA. Modeltest (version 3.7macX, Posada and Crandall, 1998) was used to select a model of evolution for the nucleotide data using the Akaike Information Criterion. Phylogenetic trees were constructed using Bayesian inference (BI) (MrBayes, version 3.2.1, Huelsenbeck \& Ronquist, 2001). Likelihood settings were set to $n s t=6$, rates=invgamma, ngammacat $=4$ (equivalent to the $\mathrm{GTR}+\mathrm{I}+\mathrm{G}$ model of evolution). In the combined lsr + ssrDNA analysis, parameters were estimated separately for each gene. Two chains (temp $=0.2)$ were run for $5,000,000$ generations and sampled every 1000 generations. Post-'burnin' was identified when the standard deviation of split frequency reached $<0.01 .2$ million and 4.5 million generations were discarded as burnin in the combined lsr+ssrDNA analysis and single gene analyses, respectively. Nodes with $<0.95$ posterior 
probabilities (pp) were collapsed in all the figures.

\section{Results}

\section{Taxonomy}

Remarks. The three taxa forming the focus of this study are classified below according to conventional morphology-based taxonomy and nomenclature. Changes to this classification implied by the findings of the molecular phylogenetic analysis can be found in the Discussion section at the end of the paper.

\section{Suborder Tubuliporina Milne Edwards, 1838 \\ Family Diaperoeciidae Canu, 1918 \\ Genus Diaperoecia Canu, 1918}

Type species. Pustulopora intricaria Busk, 1875; Recent, Australia.

Remarks. Several genera of tubuliporine cyclostome bryozoans, both living and fossil, have 'vinculariiform' colonies comprising narrow bifurcating branches with autozooids opening evenly around the entire circumference. They include Entalophora Lamouroux, 1821, Pustulopora Blainville, 1830, Collapora Quenstedt, 1881, Diaperoecia Canu, 1918, Mecynoecia Canu, 1918, Entalophoroecia Harmelin, 1976 and Annectocyma Hayward \& Ryland, 1985. With the exception of Entalophora, which is characterized by having an axial lumen (Walter, 1970), characters of the gonozooid provide the main means of distinction between these genera but are not always clear-cut and the taxonomy of these cyclostomes remains unclear.

Canu (1918, p. 329) diagnosed Diaperoecia thus: "L'ovicelle est elliptique ou suborbiculaire; elle entoure les péristomes d'un assez grand nombre de tubes qui ne sont pas dérangés dans leurs positions respectives. L'oeciostome isolé et subcentral.” (The gonozooid is elliptical or suborbicular; it surrounds the peristomes [of the autozooids] a fairly large number of which are not disturbed in their respective (?) positions. The ooeciostome is isolated and subcentral.)

Brood (1976) redescribed Busk's (1875) type specimens of Pustulopora intricaria, noting that the material subsequently placed in this species by Harmer 
(1915) from near Sorong in Indonesia was not conspecific. This is unfortunate because Canu (1918) based his concept of Diaperoecia, and consequently on the family Diaperoeciidae, on the gonozooids present in Harmer's material, whereas Busk's types are infertile. Key skeletal characters visible in the Australian type material of $D$. intricaria are illustrated in Figs 3-8. Flange-like kenozooidal projections are developed on the sides of some branches (Figs 3, 4). The spacing of apertures across the colony surface is irregular (Figs 3, 4), reflecting a high degree of variability in the lengths of the autozooids. Peristomes are short and some apertures are closed by terminal diaphragms (Fig. 5). Autozooidal frontal walls have closely spaced, subcircular pseudopores (Fig. 6). Transversely fractured branches (Fig. 7) show the presence of small buds near the branch axis and the triple-layered interior walls illustrated in thin section by Brood (1976, fig. 1C). Mural spines are present, some with a shaft and a barbed head (Fig. 8). A similar suite of skeletal characters is evident in Pustulopora purpurascens (Hutton, 1877) and this species from New Zealand can therefore be assigned on morphological grounds without reservation to Diaperoecia.

\section{Diaperoecia purpurascens (Hutton, 1877)}

(Figs 1, 9-20, 47-49, 53-55)

Pustulipora [sic] purpurascens Hutton, 1877: 361. Pustulipora [sic] purpurascens. Hutton, 1880: 198. Entalophora purpurascens. - Hutton, 1891: 107. Diaperoecia purpurascens. - Taylor et al., 2004: 57, fig. 2A, B. Diaperoecia purpurascens. Taylor et al., 2007: 220, fig. 1. Diaperoecia purpurascens. - Gordon et al., 2009: 293. Diaperoecia purpurascens. - Smith \& Gordon 2011: 36.

Material. NHMUK 2010.6.25.2 (Fig. 1), 75.1.5.33, 75.1.5.38, 99.7.1.4060-1 (Busk Collection), all from unknown localities in New Zealand. NHMUK 2014.12.17.2 (Figs 9-12, 16), East Ulva Island, Paterson Inlet, Stewart Island, 8/6/1995, D. Foster and A. M. Smith Collection. NHMUK 2017.12.17.3 (Figs 13, 14), 2017.12.17.4 (Fig. 15), craypot at Waitangi, Chatham Island, 4/11/1999, P. D. Taylor Collection. NHMUK 2017.12.17.5 (Figs 17, 18), molecular voucher specimen AW578, 46.93요 168.16 ${ }^{\circ}$ E, 39 m, Otago Shelf, New Zealand, A. M. Smith Collection, 25/1/2010. NHMUK 90.10.25.3, Wanganui. National Museum of New Zealand BS 862 (Figs 19, 
47-49), outside Whangaroa Harbour, 25 m, 26/1/1981. NHMUK BZ 7733 (Fig. 20), Pleistocene, Nukumaruan, Nukumaru Brown Sand, Nukumaru Beach, 01/2014, P. D. Taylor Collection.

Description. Colony erect, bush-like (Fig. 1), up to $8 \mathrm{~cm}$ in diameter, consisting of narrow, bifurcating branches; branch diameter $0.71-2.20 \mathrm{~mm}$, typically $1.0-1.5 \mathrm{~mm}$ (see Taylor et al., 2007, table 1). Colour in life creamy-brown, purplish-brown postmortem. All zooidal polymorphs fixed-walled, developing pseudoporous frontal walls away from branch growth tips. Autozooids elongate, frontal walls ranging in length from $0.65-2.24 \mathrm{~mm}$ (typically about $1 \mathrm{~mm}$ ) by in width $0.19-0.48 \mathrm{~mm}$ (typically 0.25 $\mathrm{mm}$ ), crossed by concave growth lines, zooidal boundaries slightly salient (Figs 9 , 10); pseudopores teardrop-shaped, pointed distally (Fig. 11); apertures subcircular, about $0.14-0.19 \mathrm{~mm}$ in diameter, disposed around entire branch circumference, sometimes almost quincuncially arranged but in other cases unevenly spaced and occasionally clustered into small groups; peristomes short; terminal diaphragms closing older zooids (Fig. 18), sparsely to densely pseudoporous. Kenozooids infrequent. Gonozooids longitudinally elongate (Figs 13-15), $>4 \mathrm{~mm}$ in total length by $0.6-0.8 \mathrm{~mm}$ wide, inconspicuous, the frontal wall only slightly convex, extending distally of ooeciopore typically as lobes in daughter branches following bifurcation, lateral edges indented by neighbouring autozooids but roof seldom pierced by autozooids; pseudopore density higher than in autozooids; ooeciopore subcircular (Fig. 14), slightly smaller than neighbouring autozooidal apertures, about $0.16 \mathrm{~mm}$ in diameter, located non-terminally; ooeciostome very short.

Early astogeny observed in two colonies, one recent (Fig. 19), the other an Early Pleistocene fossil (Fig. 20). Fan-like encrusting base giving rise to three erect stems in both cases. Ancestrula (Figs 53-55) curved to the right, $0.83-1.09 \mathrm{~mm}$ long, with longitudinally elliptical aperture $0.16-0.19 \mathrm{~mm}$ long by $0.14-0.17 \mathrm{~mm}$ wide, occluded by a terminal diaphragm in the recent example but open in the fossil. Protoecium large, $0.33-0.37 \mathrm{~mm}$ in transverse diameter; pseudopores confined to a crescentic marginal band, closely but irregularly spaced, subcircular, countersunk, external diameter $c .12 \mu \mathrm{m}$, internal diameter $c .6 \mu \mathrm{m}$. Non-pseudoporous distal part of protoecium elevated and with chevron-shaped transition to ancestrular tube which has a rugose surface with non-countersunk pseudopores. 
Mural spines developed on surfaces of interior walls and internal surfaces of frontal exterior walls, with a moderately long shaft a head covered by sharp barbs, either symmetrically or more often only on the side facing proximally. Distal edges of interior walls exhibiting transversely fibrous ultrastructure.

Remarks. The whereabouts of Hutton's (1877) material of this species is unknown. Although it is known that he sent many of his samples to the then British Museum (Natural History), none could be found appropriately labelled as having originated from F. W. Hutton. Given that there is no controversy about the identity of this species, there is currently no justification for erecting a neotype.

Distribution. Widespread in the seas around New Zealand at the present-day, this species also occurs as a fossil back to at least the Late Pliocene and is especially abundant in the Pleistocene Tainui Shell Bed of Wanganui (PDT, pers obs). Taylor et al. (2004, fig. 4C) showed the distribution of D. purpurascens based on 137 NZOI station samples, ranging in latitude from $33-54{ }^{\circ} \mathrm{S}$, and in depth from $0-1156 \mathrm{~m}$, although material from the deeper stations may have been transported downslope and $90 \%$ of records are shallower than $250 \mathrm{~m}$.

Family Hastingsiidae Borg, 1944

Genus Hastingsia Borg, 1944

Type species. Hastingsia irregularis Borg, 1944; Recent, Antarctica.

Remarks. Borg (1944) assigned three new species to his new genus Hastingsia which he placed in the new monogeneric family Hastingsiidae. He remarked on how the autozooids could open singly or in fascicles on the frontal sides of the branches, with gonozooids located in branch axils. All three of the species assigned to Hastingsia were recorded by Borg from Antarctica, although one - H. gracilis (MacGillivray, 1883) - was originally described from Victoria, Australia.

'Hastingsia' whitteni sp. nov.

(Figs 21-26, 56-58) 
Idmonea giebeliana Stoliczka - Hutton, 1873: 102 [non Idmonea giebeliana Stoliczka, 1865]. Fasciculipora ramosa d'Orbigny - Gordon, 1967: 63, fig. 45 [non d'Orbigny, 1842]. Fasciculipora ramosa - Morton \& Miller, 1968: 227, 575, figs 76, 214 [non d'Orbigny, 1842]. Hastingsia maoriana Whitten MS 1979: 379, pl. 22, figs 4, 5. Hastingsia n. sp. 2 - Gordon et al. 2009: 293. Hastingsia cf. 'giebeliana' Stolickza - Gordon et al. 2009: 293 [non Idmonea giebeliana Stoliczka, 1865].

Etymology. Named for Ronald F. Whitten who first recognised this as a new species and gave description of it in his unpublished $\mathrm{PhD}$ thesis (Whitten, 1979).

Material. Holotype: NIWA 98120 (Fig. 23), Auckland, on Sargassum sinclairii, 3/1/1996, D. P. Gordon Collection. Paratypes: NIWA 98121 (Figs 24, 56-58), details as for holotype. NHMUK 2017.12.17.6 (Fig. 21), 2017.12.17.7 (Figs 22, 25),

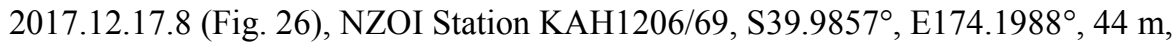
20/4/2012, molecular voucher specimen AW757.

Description. Colony encrusting (Fig. 23), becoming semi-erect (Fig. 26), small, adnate branches bifurcating; pale brownish-cream when alive, purplish-brown postmortem. All zooidal polymorphs fixed-walled, developing pseudoporous frontal walls away from branch growth tips. Autozooids elongate, frontal walls rugose with moderately developed growth lines (Fig. 25), zooidal boundaries grooved slightly, pseudopores subcircular, density decreasing into peristomes; apertures subcircular to rounded quadrate when connate, about $0.18 \mathrm{~mm}$ in diameter, usually clustered into small groups (Figs 21, 23, 25, 26) but sometimes isolated; peristomes long, up to at least $1 \mathrm{~mm}$ (Fig. 25); terminal diaphragms not observed. Kenozooids not observed. Gonozooids appearing in early astogeny, longitudinally elongate, at least $1.5 \mathrm{~mm}$ in total length by $1.2 \mathrm{~mm}$ wide, inconspicuous, the frontal wall only slightly convex, boundaries ill-defined (Fig. 21), enclosing some autozooidal peristomes; pseudopore density slightly higher than in the autozooids; ooeciopore not identified but a small aperture, 0.10 by $0.13 \mathrm{~mm}$, in the roof of one gonozooid may be an ooeciopore.

Ancestrula large (Figs 21, 23, 25, 56-58), only a little smaller than later budded autozooids, $0.79-0.82 \mathrm{~mm}$ long, with subcircular aperture $0.16-0.18 \mathrm{~mm}$ in diameter. Protoecium large, $0.39-0.44 \mathrm{~mm}$ in transverse diameter; pseudopores confined to a crescentic marginal band, irregularly spaced, subcircular, countersunk, 
external diameter c. $12 \mu \mathrm{m}$, internal diameter c. $6 \mu \mathrm{m}$. U-shaped transition to ancestrular tube which has a rugose surface and non-countersunk pseudopores.

Mural spines present in autozooids, including the ancestrula, and gonozooids (Fig. 24); branched (in brood chambers) or unbranched with barbed heads (Fig. 22). Transversely fibrous ultrastructure visible at wall growing edges.

Remarks. This new species differs from the type species of Hastingsia, H. irregularis Borg, 1944), in having larger autozooids and gonozooids, and in not developing extensive erect growth. The linear fascicles depicted by Bock (http://www.bryozoa.net/cyclostomata/hastingsiidae/hastgra.html) in H. gracilis (MacGillivray, 1884) have no equivalent in ' $H$ '. whitteni sp. nov., and the gonozooid in this Australian species is ovoidal with a strongly compressed ooeciopore, contrasting with the new species. The tiny gonozooid of the erect H. pygmaea Borg, 1944, the only other species assigned to Hastingsia, contrasts with the voluminous gonozooid of $H$. whitteni sp. nov.

This is the first formally published record of Hastingsia in New Zealand, although Whitten (1979) referred an undescribed species to this genus in his unpublished $\mathrm{PhD}$ thesis. In addition, three fragments from New Zealand donated to the NHMUK collection by F.W. Hutton (NHMUK 75.1.5.35) and labelled by Hutton Idmonea giebeliana Stoliczka, 1865 can be assigned to ' $H$ '. whitteni. In addition, 'Fasciculate sp. 2' of Boardman (1998, p. 29, fig. 75) from Leigh, and the un-named fasciculate cyclostome also from New Zealand figured by Taylor (2000, fig. 6), are both apparently this species.

Material in the NIWA collections identified tentatively as the type species of Hastingsia, H. irregularis, includes a broken protoecium which seemingly lacks pseudopores and therefore differs significantly from that of ' $H$ '. whitteni, underscoring the problem of assigning the New Zealand species to a genus.

Distribution. Northeastern North Island, New Zealand, Auckland to Whangarei, including Hauraki Gulf from where Whitten (1979) obtained his material.

Suborder Cerioporina von Hagenow, 1851

Family Cerioporidae Busk, 1859

Genus Heteropora de Blainville, 1830 
Type species. Ceriopora cryptopora Goldfuss, 1826; Cretaceous, Maastrichtian, The Netherlands.

Remarks. There are unresolved problems over the concept of the genus Heteropora owing to the fact that the Cretaceous type species (see Nye, 1976) differs substantially from the extant species, including H. neozelanica Busk, 1879 described below, which have been assigned to the genus. One solution (e.g., Gordon et al., 2009) has been to refer these recent species to another cerioporid genus Tetrocycloecia Canu, 1917, with a Miocene type species (see Taylor \& McKinney, 2006, p. 51) but this too may not be congeneric with the species described below.

\section{'Heteropora' neozelanica Busk, 1879}

(Figs 2, 27-45, 50-52, 59-61)

Heteropora neozelanica Busk, 1879: 724, pl. 15, figs 1-4. Heteropora neozelanica. Nicholson, 1880: 329, figs 1A-C, 2. Heteropora pelliculata Waters. - Hutton, 1891: 107. Heteropora neozelanica. - Borg, 1933: 306, text-figs 12-14, pl. 5, figs 1-5, pl. 6, figs 3, 4, pl. 7, figs 1-3, pl. 10, figs 1, 2. Heteropora neozelanica. - Borg, 1944: 210, pl. 16, fig. 1. Tetrocycloecia neozelanica. - Gordon et al., 2009: 293.

Tetrocycloecia spp. - Smith \& Gordon 2011: 31.

Material. Lectotype (chosen here): NHMUK 99.7.1.4281 (Figs 27, 28, 30, 31), New Zealand. It is evident that Busk (1879) had more than one specimen at his disposal when he erected Heteropora neozelanica as he remarked that Nicholson had furnished him with some very fine specimens of this species. However, his figures (Busk, 1879, pl. 15, figs 1-4) could conceivably be from a single specimen. Busk's figure 1, which is reproduced here as Fig. 27, depicts an intact ramose colony. Unfortunately, it is not possible to match this or the any of the higher magnifications views (pl. 15, figs 2-4) with material labelled as 'type' in the Busk Collection at the NHMUK and it seems possible that the intact colony is either lost or has been broken-up into the fragments that are now mounted on slides. One of these (Fig. 28, 30,31) is herein chosen as the lectotype of ' $H$ '. neozelanica. Neither Busk (1879) nor Nicholson (1880) gave any more detailed information than simply New Zealand. 
Paralectotype: NHMUK 99.7.1.4280 (Figs 29, 32), Nicholson Collection.

Other material: NHMUK 2014.12.17.1 (Figs 2, 33, 36, 40-45, 50-52), Otago Shelf, Stn Mu88-29, 87-89 m, 11/5/1988, P. D. Taylor Collection. NHMUK 2014.12.17.9 (Figs 34,37 ), molecular voucher specimen AW086, $46.42^{\circ} \mathrm{S}, 167.58^{\circ} \mathrm{E}, 54 \mathrm{~m}$, The Snares, New Zealand, A. M. Smith \& J. Porter Collection, February 2008. NIWA 98122 (Figs 59-61), NZOI Stn Z9684, 34²3.55’S, 17251.72’E, 40 m, 26/1/1999. Comparative material (Heteropora sp.): NHMUK 2014.12.17.10 (Figs 35, 38), molecular voucher specimen NZ064, $47.08^{\circ} \mathrm{S}, 168.12^{\circ} \mathrm{E}, 94 \mathrm{~m}$, The Snares, New Zealand, A. M. Smith \& J. Porter Collection, 29/1/2008.

Description. Colony erect, bush-like (Figs 2, 27), $7 \mathrm{~cm}$ or more in diameter, consisting of bifurcating branches. Pale yellow to pale brownish-yellow in life, pale creamy brown to purplish-brown post-mortem. Branch diameter variable between colonies, ranging from 0.7-2.2 mm, most often 2.0-6.0 mm, increasing modestly from distal branch tips to branch bases, mean value variable between colonies. Zooidal polymorphs predominantly free-walled, apart from gonozooids, which have fixed-walled brood chamber roofs (Figs 42, 43), zooids from early astogeny, and old branches and occasional patches of autozooids with short peristomes of exterior wall and kenozooids closed by terminal diaphragms (Figs 39, 40, 43-45). Distinction between autozooids and kenozooids sometimes obscure (Fig. 36). Autozooidal apertures subcircular, about $0.19-0.24 \mathrm{~mm}$ in diameter, rim often slightly raised; exterior-walled peristomes rarely developed, sparsely pseudoporous, short, $<1 \mathrm{~mm}$ high (Figs 40, 44, 45). Basal diaphragms present close to endozone/exozone boundary in some autozooids (Fig. 32). Kenozooids more numerous than the autozooids which they surround entirely, apertures rounded polygonal, typically smaller and more variable in diameter than autozooidal apertures, equidimensional or elongate, about $0.08-0.28 \mathrm{~mm}$ wide, thick-walled with sharp zooidal boundaries; some kenozooids closed by terminal diaphragms accreted centripetally, with closely-spaced pseudopores about $10 \mu \mathrm{m}$ in size, often teardrop-shaped, located slightly to appreciably proximally of apertural rims. Gonozooids subcircular (Fig. 42), variable in size, $1.4-3 \mathrm{~mm}$ in diameter, roof bulging very slightly, formed of densely pseudoporous exterior wall accreted centrifugally from the peristomes of autozooids passing through brood chamber, margins becoming overgrown by surrounding zooids; ooeciopore located about midway between centre and distal edge, 
approximately the same size as an autozooidal aperture, compressed, $0.19 \mathrm{~mm}$ long by $0.12 \mathrm{~mm}$ wide in the single example studied (Fig. 42); ooeciostome short, slightly flared.

Early astogeny observed in two colonies, both from NZOI Station Z9684 in Spirits Bay, northern New Zealand. Fan-like encrusting base giving rise to a single erect stem. Ancestrula_Figs 59-61) 0.77-1.05 mm long, with subcircular aperture $0.17-0.18 \mathrm{~mm}$ long by $0.13-0.18 \mathrm{~mm}$ wide, occluded by a terminal diaphragm in one example. Protoecium large, $0.38-0.46 \mathrm{~mm}$ in transverse diameter; pseudopores confined to a crescentic marginal band, closely but irregularly spaced, subcircular, countersunk, external diameter $c .10 \mu \mathrm{m}$, internal diameter c. $5 \mu \mathrm{m}$. Shallow Ushaped transition to ancestrular tube which has a rugose surface with non-countersunk pseudopores.

Mural spines present in both autozooids and kenozooids, tending to be more numerous and longer in the latter; varies in morphology, many with a smooth shaft bearing a head covered by sharp barbs, longest around circumference of head and downwardly curved; shaft sometimes dividing distally into two or three branches, each with a barbed head; other mural spines with a single long barb directed proximally and resembling the beak on a bird's head. Distal edges of walls exhibit transversely fibrous ultrastructure.

Remarks. Material provisionally assigned to this species varies widely in branch diameter. Busk's syntypes have branches $5-6 \mathrm{~mm}$ in diameter, whereas the branches in colonies from the Otago Shelf vary from the same size (see colour photo in Smith $\&$ Gordon, p. 31) to about half this size (e.g. Fig. 2). Other aspects of the skeletal morphology, however, seem indistinguishable. In view of the depth-related variability in branch diameters between colonies of Heteropora pacifica Borg, 1933 from Washington State described by Schopf et al. (1980), the possibility that branch diameter in ' $H$ '. neozelanica also varies ecophenotypically cannot be excluded. Therefore, ' $H$ '. neozelanica is here interpreted in a broad sense to encompass most species of 'Heteropora' from New Zealand waters with widely ranging branch diameters.

The molecular phylogenetic analysis below revealed more than one clade of 'Heteropora' in New Zealand. Comprehensive research combining morphological and molecular analyses of material from multiple localities around New Zealand will 
be needed to unravel the complexity of this group of species. This is beyond the scope of the current study.

Neither Busk (1879) nor Nicholson (1880) described the gonozooids of this species. Borg (1933) too was unable to identify them with certainty in the material he had available for study but he believed that some enlarged apertures visible on colony surfaces were possibly ooeciopores of overgrown gonozooids. However, it is clear from his figure (pl. 5, fig. 5) that these supposed ooeciopores are tubes formed by the bryozoan around a symbiont such as a spionid polychaete (cf. Ernst et al., 2014). Unequivocal examples of gonozooids are present in material of ' $H$ '. neozelanica from the Otago Shelf. These show the exterior-walled roof supported by autozooids passing through the brood chamber (Figs 42,43) and an ooeciopore of about the same size as an autozooidal aperture but laterally compressed.

Distribution. Widely distributed in waters around New Zealand at the present-day, at least from Spirits Bay in the north to Foveaux Strait in the south, as well as The Snares.

\section{Molecular phylogenetics}

Figure 46 depicts the molecular phylogeny based on the concatenated dataset of lsr+ssrDNA, in which the newly sequenced taxa 'Hastingsia' whitteni sp. nov. and Diaperoecia purpurascens were analysed in the context of the previously published cyclostome phylogenies of Waeschenbach et al. (2009) and Taylor et al. (2011). The tubuliporine Annectocyma tubulosa forms the sister group to a clade composed of the cerioporines 'Heteropora' sp. (molecular specimen NZ064), 'Heteropora' neozelanica (molecular specimen AW086) and the tubuliporines 'Hastingsia' whitteni sp. nov. (molecular specimen AW757) and Diaperoecia purpurascens (molecular specimen AW578), where 'Heteropora' sp. forms the sister group to an unresolved assemblage of the latter three taxa (Fig. 46). The same topology for this grouping was obtained in analyses using the single gene partitions (Online Supplementary Material), but the node that places 'Heteropora'sp. as the sister group to 'Hastingsia' whitteni sp. nov. + 'Heteropora' neozelanica + Diaperoecia purpurascens is only weakly supported in the lsrDNA only analysis (0.72 pp). 


\section{Discussion}

The results of the molecular phylogenetic analysis, which is the most comprehensive and up-to-date for cyclostomes, are unexpected because they show a close relationship between cyclostome bryozoans previously assigned to different suborders based on morphological criteria. Whereas Heteropora is traditionally assigned to the suborder Cerioporina, Diaperoecia and Hastingsia are placed in the suborder Tubuliporina, although some classifications (e.g., Walter, 1970; Ryland, 1982) would assign the latter genus to a third suborder - Fasciculina - not universally recognised. There have been no previous suggestions in the literature that Heteropora might be closely related to Diaperoecia and Hastingsia, and the only superficial similarity is their pale yellowish to yellowish-brown colour in life and generally purplish-brown post-mortem pigmentation. But can this relationship be supported using morphological characters?

The taxonomy of cyclostome bryozoans has been founded entirely on characters of the mineralized skeleton. Skeletal characters are easily visible without histological preparation, and are conserved in dried material as well as fossils. In contrast, very little is known about the soft part anatomy of cyclostome bryozoans and available data concerns only a small proportion of known species (see Boardman, 1998). Cyclostome suborders have been recognized mainly according to the types of skeletal walls employed by the autozooids and gonozooids.

There are two basic types of skeletal walls in cyclostomes (and other bryozoans): interior and exterior (see Taylor et al., 2014). Interior skeletal walls partition body cavities and are secreted by an epithelium that is present on both sides and wraps around the distal end of the wall. They lack a cuticular outer layer. Exterior skeletal walls are located at the interface between the bryozoan and the environment, and are secreted by an epithelium present on the body cavity side only, the opposite side being covered by a layer of cuticle. When no frontal exterior walls are developed a hypostegal cavity (coelom or pseudocoel) invests the colony, forming a continuous layer that connects the body cavities of the zooids over the outer ends of their interior walls. This skeletal organization was termed ‘double-walled' by Borg (1926), later renamed 'free-walled'. In contrast, cyclostomes with frontal exterior walls lack a 
hypostegal cavity investing the colony, an organization termed 'single-walled' by Borg but now known as 'fixed-walled'.

Two cyclostome suborders (Tubuliporina and Articulata) possess fixed-walled autozooids and gonozooids (i.e., with exterior frontal walls), one order (Cerioporina) has free-walled autozooids but fixed-walled gonozooids, while the other two suborders (Rectangulata and Cancellata) have free-walled autozooids and gonozooids. To Borg (1926) and many later authors, free- vs. fixed-walled skeletal organizations represented fundamental differences of high taxonomic value. Indeed, it has been argued that modern free-walled cyclostomes are more closely related to various orders of free-walled Palaeozoic bryozoans than they are to the fixed-walled cyclostomes (e.g., Boardman, 1984; Viskova, 1992).

The value of skeletal organization in high-level cyclostome taxonomy has been challenged in recent years, firstly by the recognition of taxa showing mixtures of the two organizational types, and subsequently by molecular phylogenetic evidence. Taylor (2000) pointed to examples of mixing free- and fixed-walled organizations in seemingly monophyletic cyclostome taxa (e.g., Eleidae, Cinctiporidae), and even in single colonies (e.g., Cinctipora elegans: see Boardman et al., 1992). A particularly clear example is Spiritopora perplexa Taylor \& Gordon, 2003, in which the zooids in the extensive lamellar base of the colony are normally fixed-walled, whereas those forming the erect fronds are predominantly free-walled.

Molecular phylogenetic studies of cyclostomes have recovered trees showing no clear separation between free- and fixed-walled species. Waeschenbach et al. (2009) assembled a tree using sequence data from 22 species of cyclostomes, showing poor congruence with traditional classifications based on skeletal organization; transitions between free-and fixed-walled conditions, or vice-versa, have apparently occurred several times during cyclostome evolution. A subsequent molecular study (Taylor et al., 2011) showed the dominantly free-walled cyclostome Tennysonia to group with the fixed-walled tubuliporine Idmidronea, despite the additional difference in the morphology of Tennysonia, which has kenozooids as spacers between the autozooidal apertures.

In the light of this accumulating evidence for plasticity in skeletal organization, it is perhaps unsurprising to find the fixed-walled tubuliporines Diaperoecia purpurascens and 'Hastingsia' whitteni in the same molecular clade as the free-walled cerioporine 'Heteropora' neozelanica. As with the clade containing 
Idmidronea and Tennysonia, a further difference is apparent in the manner in which the apertures of the autozooids - and hence the lophophores in living colonies - are spaced apart. Areas of the colony surface between the autozooidal apertures of $D$. purpurascens and 'Hastingsia' whitteni are occupied by the calcified exterior frontal walls of the autozooids (e.g., Fig. 9), whereas in 'Heteropora' they are filled by kenozooids with open apertures (e.g., Figs 36-38). These kenozooids are best interpreted as 'normal' buds that failed to develop a polypide with a functional lophophore.

It is also worth remarking on the various forms of frontal exterior wall calcification that can be found in the predominantly free-walled 'Heteropora' neozelanica. Aside from the fixed-walled gonozooids, which are found in other cerioporine cyclostomes too, patches of exterior wall calcification are developed elsewhere on colony surfaces. They are particularly common in the proximal parts of branches (Figs 39, 40) but can also be seen in distal branches, for example adjacent to gonozooids (Figs 42-44). The kenozooids in these patches are usually closed by terminal diaphragms, either accreted distally almost as a lamina across the ends of their walls, or more proximally, leaving the distal ends of the vertical kenozooidal walls exposed above the diaphragms (Fig. 40). Autozooids in these patches often develop short exterior-walled peristomes with scattered pseudopores (Fig. 45). Peristomes are also present in the autozooids passing through brood chambers and supporting the roofs of the gonozooids (Figs 42, 43).

Three nominal species of Heteropora have been recorded from the Pacific coast of North America. Ross (1973) described the skeletal morphology of Heteropora colonies from Washington State, USA, noting the presence of what she termed 'collars' around the aperture of autozooids proximal of the branch growing tips. These collars are clearly exterior-walled peristomes very similar to those seen in New Zealand 'Heteropora'. Fixed-walled growth, therefore, is more widely distributed taxonomically in Recent species assigned to Heteropora than is generally acknowledged.

\section{Gizzard}

Despite the paucity of information on cyclostome soft-part anatomy, the molecular tree recovered here (Fig. 46) is corroborated by at least one anatomical feature, the presence of a gizzard. Gizzards are modified sections of stomach cardia with 
microvillous plates or teeth (Gordon, 1975) and apparently function to allow bryozoans to open diatom frustules (Markham \& Ryland, 1987). They have been reported in a relatively small number of bryozoans, including some ctenostome and cheilostome gymnolaemates as well as four species of cyclostomes (Schäfer, 1986). The cyclostome species having gizzards were identified as Diaperoecia major (Johnston, 1847) and D. tubulosa (Busk, 1875) by Schäfer (1986), and as Pustulopora purpurascens Hutton and 'Fasciculate sp. 2' by Boardman (1998). In all of these cyclostomes the gizzard comprises two dental plates that act like jaws. The species identified as Diaperoecia tubulosa is now Annectocyma tubulosa, a northern hemisphere species recovered as the sister-taxon to the clade of New Zealand cyclostomes described in the current paper. Boardman's (1998) Pustulopora purpurascens is Diaperoecia purpurascens, and his 'Fasciculate sp. 2', to judge from fig. 75, is probably 'Hastingsia' whitteni sp. nov. Therefore, the clade including Annectocyma tubulosa and all crownward taxa possess a gizzard as an apomorphic character, although no histological data is yet available for New Zealand species of Heteropora. The finding of a gizzard in 'Heteropora' would corroborate this character as a clade-defining apomorphy.

\section{Mural spines}

Minute spines of uncertain function grow from the skeletal walls into the zooidal chambers in many cyclostome taxa (Farmer, 1979; Taylor \& Weedon, 2000 and references therein). These zooecial or mural spines vary in morphology among species, and also within taxa, both between polymorphs and within the same polymorph.

Mural spines with long shafts supporting barbed heads covered by a few to a moderate number of spinelets occur in the three related species described above, as well as in the type species of Diaperoecia (Fig. 8). Most are unbranched (Figs 22, 4748,52 ) but some bifurcate (Fig. 51) and have a barbed head on each branch. The long spines of Heteropora neozelanica with globose densely barbed heads are also seen in species of 'Heteropora' from the Pacific Coast of North America (Farmer, 1979, textfig. 4; Weedon \& Taylor, 1996, fig. 7e) and could be taxonomically diagnostic.

However, spines with flattened heads and a small number of spinelets (Figs 8, 47-49) seem to be more taxonomically widespread. They occur, for example, in lichenoporids (Farmer, 1979, pl. 1; Dick et al., 2006, fig. 16D) which are distant in 
molecular trees (Waeschenbach et al., 2009, 2012) from the New Zealand cyclostomes described here.

Unfortunately, too little is known about the morphological variants and taxonomic distribution of mural spines for their potential in cyclostome taxonomy to be evaluated. Additionally, they have little utility in fossil cyclostomes as they are too fragile for routine preservation.

\section{Early astogeny}

Few taxonomic studies include information on the early astogeny of cyclostome bryozoans. Nevertheless, Jenkins \& Taylor (2014) considered early astogeny to be a potentially important source of higher-level taxonomic characters, given that early development may be relatively conserved in evolution and can therefore provide evidence of deep phylogenetic relationships among cyclostomes. Studying early astogenetic stages in species with large erect colonies, including Diaperoecia purpurascens and 'Heteropora', is difficult as the oldest parts of colonies may be lost or obscured by subsequent growth of the colony or fouling organisms. However, it has been possible to find examples of colonies preserving the ancestrula and other early zooids in both of these species, as well as in the smaller colonies of 'Hastingsia' whitteni. Contrary to the striking differences seen in the skeletal morphology of later astogenetic stages in these three closely related species, their early astogeny is remarkably similar.

Juvenile colonies of all three species are fan-shaped encrustations comprising fixed-walled autozooids with calcified exterior frontal walls (e.g., Figs 19, 20). One or more erect stems grow upwards from the substrate from this encrusting base. In the case of 'Heteropora', the zooids in the erect stems differ from those of the encrusting base in being free-walled, but in Diaperoecia purpurascens and 'Hastingsia' whitteni they have the same fixed-walled skeletal organization.

The greatest similarities are apparent in the ancestrula (Figs 53, 56, 59), and particularly the protoecium, which is large in all three species: $0.33-0.37 \mathrm{~mm}$ wide in D. purpurascens, $0.39-0.44 \mathrm{~mm}$ in 'Hastingsia' whitteni, and $0.38-0.46 \mathrm{~mm}$ in 'Heteropora'. These sizes compare with typical protoecial widths of $0.1-0.2 \mathrm{~mm}$ in cyclostomes (e.g., Jenkins \& Taylor, 2014).

Cyclostome protoecia exhibit interspecific variability in the number and distribution of pseudopores (Weedon, 1998). All three species from New Zealand are 
characterized by protoecia with numerous, somewhat irregularly arranged pseudopores distributed in a crescentic band around the proximal and lateral edges of the protoecium (Figs 54, 57, 60). Pseudopores are lacking from more distal parts of the protoecium but reappear on the ancestrular tube.

Not only is the distribution of protoecial pseudopores very distinctive in Diaperoecia purpurascens, 'Hastingsia' whitteni and 'Heteropora', but they are very similar in size and shape. In all three species the pseudopores are circular to elliptical and have a characteristic countersunk morphology (Figs 55, 58, 61), with an external diameter of about $10-12 \mu \mathrm{m}$ and an internal diameter of 5-6 $\mu \mathrm{m}$. In contrast, pseudopores on the ancestrular tube and later zooids are not countersunk. Weedon (1998) described such pseudopores in a specimen from the Otago Shelf (New Zealand) which he identified as Diaperoecia cf. purpurascens, noting that the pseudopores are located not only at the boundaries between the strips of calcification forming the protoecium but also, and unusually, within strips.

The ancestrula has not been described in Annectocyma tubulosa, the sistertaxon to the New Zealand clade forming the focus of the current study, and attempts to find an example in the collections of the NHMUK have been unsuccessful. A colony of the related $A$. major (Johnston, 1847), however, has a protoecium with a near-marginal band of countersunk pseudopores (Figs 62,63). The corollary is that this character may be apomorphic for a clade that includes not only the three New Zealand species under study, but also some taxa such as Annectocyma from the immediate out-group.

Figure $6 \underline{4 z}$ summarises diagrammatically how the very similar skeletal organization in the early astogenetic stages of Diaperoecia purpurascens and 'Heteropora' changes in later astogeny. In D. purpurascens, the zooids in late astogeny retain the same fixed-walled organization as those from early astogeny. Only the growing tips of the erect branches are covered by hypostegal coelom, and calcified exterior frontal walls of the autozooids form the branch surface between the everted tentacle crowns. In contrast, in 'Heteropora', the zooids in late astogeny have a free-walled organization, hypostegal coelom extends proximally from the branch growth tips to cover the entire branch surface, and kenozooids function as spacers between the everted tentacle crowns in the absence of calcified exterior frontal walls. Transitions from one state to the other can be construed as heterochronous (see Taylor, 2000). 


\section{Implications for cyclostome taxonomy}

Our molecular phylogenetic analysis recovers, with strong support, a clade of cyclostomes containing the heteromorphic assemblage of 'Heteropora spp., 'Hastingsia' whitteni and Diaperoecia purpurascens. While this clade at first seems to have a scant morphological basis, it is apparently corroborated by at least one softpart character - the presence of a gizzard - and by the skeletal morphology of the ancestrula, with distinctive countersunk pseudopores arranged in a crescent on the protoecium. These are not morphological characters previously applied in cyclostome taxonomy. Therefore, it is unsurprising that the supraspecific classification of the taxa studied here does not mirror their phylogenetic relationships. How then can these taxa be reclassified and named to reflect phylogeny better?

Cyclostome families have been defined largely on characters of the gonozooids since the work on F. Canu and R. S. Bassler in the early $20^{\text {th }}$ century. Indeed, Canu (1918) created Diaperoeciidae on the basis of the supposed morphology of the gonozooid of Diaperoecia intricaria (Busk) (but see above), which he described as elliptical or suborbicular, surrounding autozooidal apertures and with a subcentral ooeciopore. While the gonozooids of Diaperoecia purpurascens, 'Hastingsia' whitteni and 'Heteropora' could just about all be accommodated within this diagnosis, there are major differences in structure of the gonozooids between the first two species and 'Heteropora'. Gonozooids of D. purpurascens and ' $H$ '. whitteni have roofs that calcify in a distal direction, parallel to the frontal walls of the adjacent autozooids. The roofs in 'Heteropora', however, calcify radially outwards from the autozooids that penetrate the brood chamber.

Notwithstanding the problems posed by the lack of knowledge of gonozooid morphology in the type species of Diaperoecia, and the substantial contrast in the growth pattern of the gonozooids described above, the family Diaperoeciidae can be used to accommodate the three species from New Zealand studied here if it is redefined using other morphological characters, viz. the presence of a gizzard, and a protoecium with a marginal band of countersunk pseudopores. As both of these characters are also found in species of Annectocyma, this genus can also be included in Diaperoeciidae. The family Annectocymidae Hayward \& Ryland, 1985 then becomes a junior synonym of Diaperoeciidae Canu, 1918. 
More problematical are the most appropriate generic names for the species here rererred to as 'Hastingsia' whitteni and 'Heteropora' spp. While it would be justifiable to place all of these species in Diaperoecia given their close phylogenetic affinities to $D$. purpurascens, this would conceal the strong morphological differences between these taxa. On the other hand, the identities of both 'Hastingsia' whitteni and 'Heteropora' require clarification through detailed studies of their generic type species, including early astogeny and, in the case of the extant type species of Hastingsia, soft-part anatomy to ascertain whether a gizzard is present and sequence data to fix its position on the molecular tree. Pending this research, the generic names Hastingsia and Heteropora are retained as 'form-genera' for the species described here from New Zealand.

Finally, a serious difficulty is posed by the non-monophyletic status of the species identified here as 'Heteropora'. Sequenced specimens categorized morphologically as belonging to this genus - taking into account the high degree of variation in skeletal characters evident within colonies (see above) - appear as two branches on the molecular tree (Fig. 46) One branch is part of an unresolved assemblage including Diaperoecia purpurascens and 'Hastingsia' whitteni, while the other is sister to the clade containing all these three taxa. There are two possible evolutionary interpretations: (1) the 'Heteropora' morphotype with its predominantly free-walled skeletal organization evolved twice, or (2) the fixed-walled 'Hastingsia' whitteni and Diaperoecia purpurascens evolved from a heteroporid ancestor. The unresolved nature of the node in question means that no inferences can be made about the independent acquisition of the types of skeletal organization, although there is moderate support for a sister-group relationship between 'Heteropora' neozelanica and Diaperoecia purpurascens in two of the analyses [1sr+ssrDNA: 0.93 pp (result not shown); ssrDNA: 0.92 pp (Supplementary Fig. 2)], which points to independent acquisitions of either fixed-walled skeletal organization from a free-walled ancestor or vice versa. Sequence data from additional specimens of 'Heteropora' from New Zealand and elsewhere should help in testing these alternatives.

\section{Conclusions}

1. The skeletal morphology is described in three species of cyclostome bryozoans from New Zealand - Diaperoecia purpurascens (Hutton, 1877), 'Hastingsia' 
whitteni sp. nov. and 'Heteropora' neozelanica Busk, 1879 - based on SEM of type and other material.

2. Traditional taxonomy places these species in three separate families (Diaperoeciidae, Hastingsiidae and Cerioporidae (=Heteroporidae)) and two or three suborders, reflecting major differences in their skeletal morphology.

3. A molecular phylogenetic analysis showed, however, that the three heteromorphic species are closely related and form a clade that is sister to Annectocyma.

4. Morphological support for this 'diaperoeciid' clade + Annectocyma comes from the presence of a gizzard (yet to be proven as present in 'Heteropora' neozelanica) and the skeletal morphology of the earliest part of the colony, the protoecium. In all of these taxa, the protoecium is large and has a peripheral band of countersunk pseudopores.

5. The occurrence of fixed- and free-walled species in the diaperoeciid clade further underscores the plasticity in skeletal organization exhibited by cyclostome bryozoans. 6. Until more is known about the type species of both Hastingia and Heteropora, these genus names are best employed as form-genera for 'Hastingsia' whitteni, 'Heteropora' neozelanica and 'Heteropora' sp.

7. Much work remains to be done on assembling a more complete molecular tree of cyclostomes and in identifying morphological characters supportive of the clades that can be identified on molecular grounds. Only then will it be possible to overhaul the morphological classification of cyclostomes currently in use and replace it with one that is more reflective of phylogeny.

\section{Acknowledgements}

Research on cyclostome bryozoans from New Zealand was commenced during the tenure of a British Council Link Programme Grant in the mid-1990s, and continued during NERC Grant (NE/E015298/1; October 2007-October 2010). DPG's research was supported by NIWA through Coasts and Oceans Research Programme 2 (Marine Biological Resources) taxonomy project COBR1502. PDT is grateful to Dr Lee Hsiang Liow (University of Oslo) for the opportunity to visit New Zealand for geological fieldwork in January 2014 when the specimen shown in Fig. 20 was collected. We thank Joanne Porter (Heriot-Watt University, Edinburgh) for her help with the collection of specimens, and the NHM sequencing facility for their 
sequencing expertise. The sequenced material of 'Hastingsia' whitteni sp. nov. was collected as part of a commercial project for Trans Tasman Resources (TTR) Ltd (TTR11301 Benthos and TTR11301 Deepwater); TTR is thanked for permission to use the specimen for research purposes.

\section{References}

Blackwell, M., Henk, D. A. \& Jones, K. G. (2003). Extreme morphological divergence: phylogenetic position of a tremite ectoparasite. Mycologia, 95, 987992.

Blainville, H. M. D. de (1830). Zoophytes. Dictionnaire des Sciences Naturelles, 60, $1-631$.

Boardman, R. S. (1984). Origin of the Post-Triassic Stenolaemata (Bryozoa): a taxonomic oversight. Journal of Paleontology, 58, 19-39.

Boardman, R. S. (1998). Reflections on the morphology, anatomy, evolution, and classification of the Class Stenolaemata (Bryozoa). Smithsonian Contributions to Paleobiology, 86, 1-59.

Boardman, R. S., McKinney, F. K. \& Taylor, P. D. (1992). Morphology, anatomy, and systematics of the Cinctiporidae, new family (Bryozoa: Stenolaemata). Smithsonian Contributions to Paleobiology, 70, 1-81.

Bock, P. E. \& Gordon, D. P. (2013). Phylum Bryozoa Ehrenberg, 1831. Zootaxa, $3703,67-74$.

Borg, F. (1926). Studies on recent cyclostomatous Bryozoa. Zoologiska Bidrag fran Uppsala, 10, 181-507.

Borg, F. (1933). A revision of the Recent Heteroporidae (Bryozoa). Zoologiska Bidrag fran Uppsala, 14, 253-394.

Borg, F. (1944) The Stenolaematous Bryozoa. In S. Bock (Ed.), Further Zoological Results of The Swedish Antarctic Expedition 1901-1903 (pp. 1-276). Stockholm: Norstedt and Söner.

Bourret, A., McPeek, M. A. \& Turgeon, J. (2011). Regional divergence and mosaic spatial distribution of two closely related damselfly species (Enallagma hageni and Enallagma ebrium). Journal of Evolutionary Biology, 25, 196-209. 
Brood, K. (1976). Note on the bryozoan Pustulopora (Diaperoecia) intricaria Busk, 1875. Zoologica Scripta, 5, 231-233.

Busk, G. (1859). A monograph of the fossil Polyzoa of the Crag. London: Palaeontographical Society, $136 \mathrm{pp}$.

Busk, G. (1875). Catalogue of the Marine Polyzoa in the Collection of the British Museum. Part III. Cyclostomata. London: Trustees of the British Museum, 39 pp.

Busk, G. (1879). On Recent species of Heteropora. Journal of the Linnean Society (Zoology), 14, 724-726.

Canu, F. (1917). Etudes sur les ovicelles des Bryozoaires Cyclostomes. Bulletin de la Société Géologique de France, (4), 17, 345-347.

Canu, F. (1918). Les ovicelles des Bryozoaires Cyclostomes. Etudes sur quelques familles nouvelles et anciennes. Bulletin de la Société Géologique de France, (4), 16, 324-335.

Dick, M. H., Tilbrook, K. J. \& Mawatari, S. F. (2006). Diversity and taxonomy of rocky-intertidal Bryozoa on the Island of Hawaii. Journal of Natural History, 40, 2197-2257.

Ernst, A., Taylor, P. D. \& Bohatý, J. (2014). A new Middle Devonian cystoporate bryozoan from Germany containing a new symbiont bioclaustration. Acta Palaeontologica Polonica, 59, 173-183.

Farmer, J. D. (1979). Morphology and function of zooecial spines in cyclostome Bryozoa: implications for paleobiology. In G. P. Larwood \& M. B. Abbott (Eds) Advances in bryozoology (pp. 219-246). London: Academic Press.

Goldfuss, G. A. (1826). Petrefacta Germaniae, Abbildung und Beschreibungen der Petrefacten Deutschlands und der angreuzenden Länder. Teil 1. Dusseldorf: Arnz \& Co., 76 pp.

Gordon, D. P. (1967). A report on the ectoproct Polyzoa of some Auckland shores. Tane (Journal of the Auckland University Field Club), 13, 43-76.

Gordon, D. P. (1975). The resemblance of bryozoan gizzard teeth to "annelid-like" setae. Acta Zoologica, 56, 283-289.

Gordon, D. P., Taylor, P. D. \& Bigey, F. P. (2009). Phylum Bryozoa - moss animals, sea mats, lace corals. In D. P. Gordon (Ed.), The New Zealand Inventory of Biodiversity.Volume 1. Kingdom Animalia - Radiata, Lophotrochozoa, and Deuterostomia, pp. 271-297. Christchurch: Canterbury University Press. 
Hagenow, F. von. (1851). Die Bryozoen der Maastrichter Kreidebildung. Cassel: Fischer, 106 pp.

Harmelin, J.-G. (1976). Le sous-ordre des Tubuliporina (Bryozoaires Cyclostomes) en Méditerranée. Memoires de l'Institut Oceanographique, Monaco, 10, 1-326.

Harmer, S. F. (1915). The Polyzoa of the Siboga Expedition. Part 1. Entoprocta, Ctenostomata and Cyclostomata. Siboga-Expeditie, 28a, 1-180.

Hayward, P. J. \& Ryland, J. S. (1985). Systematic notes on some British Cyclostomata (Bryozoa). Journal of Natural History, 19, 1073-1078.

Herrera-Cubilla, A. \& Jackson, J. B. C. (2014). Phylogeny of genus Cupuladria (Bryozoa, Cheilostomata) in the Neogene of tropical America. Journal of Paleontology, 88, 851-894.

Hillis, D. M. \& Dixon, M. T. (1991). Ribosomal DNA-Molecular Evolution and Phylogenetic Inference. Quarterly Review of Biology, 66, 411-453.

Huelsenbeck, J. P. \& Ronquist, F. (2001). MRBAYES: Bayesian inference of phylogenetic trees. Bioinformatics, 17, 754-755.

Hughes, R.N., Gómez, A., Wright, P. J., Moyano, H. I., Cancinao, J. M., Cravalho, G. R. \& Lunt, D. H. (2008). Molecular phylogeny supports division of the 'cosmopolitan' taxon Celleporella (Bryozoa; Cheilostomata) into four major clades. Molecular Phylogenetics and Evolution, 46, 369-374.

Hutton, F. W. (1877). Corrections and additions to the list of Polyzoa in the Catalogue of Marine Mollusca of New Zealand (1873). Transactions and Proceedings of the New Zealand Institute, 9, 358-361.

Hutton, F. W. (1880). Manual of the New Zealand Mollusca. Wellington: James Hughes, 224 pp.

Hutton, F. W. (1891). Revised list of the marine Bryozoa of New Zealand. Transactions and Proceedings of the New Zealand Institute, 23, 102-107.

Jenkins, H. L. \& Taylor, P. D. (2014). New or poorly known skeletal features in the early astogeny of some cyclostome bryozoans. Studi Trentini di Scienze Naturali, 94, 125-130.

Johnston, G. (1847). A history of the British Zoophytes. $2^{\text {nd }}$ Edition. London: John van Voorst, London, $488 \mathrm{pp}$.

Lamouroux, J. (1821). Exposition méthodique des genres de l'ordre des Polypiers. Paris: Agasse, 115 pp. 
MacGillivray, P. H. (1883). Descriptions of new or little-known Polyzoa, Part 4. Transactions and Proceedings of the Royal Society of Victoria, 19, 287-293.

Markham, J. B., \& Ryland, J. S. (1987). Function of the gizzard in Bryozoa. Journal of Experimental Marine Biology and Ecology, 107, 21-37.

Milne Edwards, H. (1838). Mémoire sur les Crisies, les Hornères et plusieurs autres Polypes vivants ou fossils don't l'organisation est analogue à celle des Tubulipores. Annales des Sciences naturelles, Zoologie et Biologie animale, Série 2, 9, 193-238.

Morton, J. \& Miller, M. (1968) The New Zealand Sea Shore. Auckland: Collins. 638 pp.

Nicholson, H. A. (1880). On the minute structure of the Recent Heteropora neozelanica, Busk, and on the relations of the genus Heteropora to Monticulipora. Annals and Magazine of Natural History, Series 5, 6, 329-339, 414-423.

Nye, O. B. Jr. (1976). Generic revision and skeletal morphology of some cerioporid cyclostomes (Bryozoa). Bulletins of American Paleontology, 69, 1-222.

Orbigny, A. D. d' (1835-47). Voyage dans l'Amérique méridionale ... execute pendant ... 1826-33 par A. D. d'Orbigny, \&c. Paris: P. Bertrand, Vol. + Atlas, 2 Vols. [Zoophytes in Vol. 5 (4), pp. 7-28, pls 1-13. Text, pp. 7-28, Livr. 89 (1847); pls 1, 3, 5, Livr. 56 (1841); pls 2, 6-8, Livr. 57 (1842); pls 4, 9, 10, 12, 13, Livr. 58 (1842); pl. 11, Livr. 59 (1842).]

Pérez, F. (2011). Discordant patterns of morphological and genetic divergence in the closely related species Schizanthus hookeri and S. grahamii (Solanaceae). Plant Systematics and Evolution, 293, 197-205.

Posada, D. \& Crandall, K.A. (1998). Modeltest: testing the model of DNA substitution. Bioinformatics, 14 (9), 817-818.

Quenstedt, F. A. (1881). Atlas zu den Röhren- und Sternkorallen. Lepizig: Fues's Verlag, pls 155-184.

Ross, J. R. P. (1973). Calcification in the colonial stenolaemate, Heteropora. In G. P. Larwood (Ed.), Living and Fossil Bryozoa. London: Academic Press, pp. 475483.

Ryland, J. S. (1982). Bryozoa. In S. P. Parker (Ed.), Synopsis and classification of living organisms. New York: McGraw-Hill, pp. 743-769. 
Schäfer, P. (1986). On the gizzard in the bryozoan genus Diaperoecia Canu (Order Tubuliporata). Senckenbergiana Maritima, 17, 253-277.

Schäfer, P. (1991). Brutkammern der Stenolaemata (Bryozoa); Konstruktionsmorphologie und phylogenetische Bedeutung. Courier Forschungsinstitut Senckenberg, 136, 1-263.

Schopf, T. J. M., Collier, K. O. \& Bach, B. O. (1980). Relation of the morphology of stick-like bryozoans to bottom currents and suspended matter and depth at Friday Harbor, Washington, Paleobiology, 6, 466-476.

Smith, A. M. \& Gordon, D. P. (2011). Bryozoans of southern New Zealand: a field identification guide. New Zealand Aquatic Environment and Biodiversity Report, $75,1-64$.

Sotiaux, A., Enroth, J., Olsson, S., Quandt, D. \& Vanderpoorten, A. (2009). When morphology and molecules tell us different stories: a case-in- point with Leptodon corsicus, a new and unique endemic moss species from Corsica. Journal of Bryology, 31, 186-196.

Stoliczka, F. (1865). Fossile Bryozoen aus dem Tertiären Grünsandsteine der OrakeiBay bei Auckland. Reise der Osterreichischen Fregatte "Novara" um die Erde in der Jahren 1857, 1858, 1859. Geologischer Theil, 1(2), 89-158.

Taylor, P. D. (2000). Cyclostome systematics: phylogeny, suborders and the problem of skeletal organization. In A. Herrera Cubilla \& J. B. C. Jackson (Eds), Proceedings of the 11th International Bryozoology Association Conference. Balboa Republic of Panama: Smithsonian Tropical Research Institute, pp. 87103.

Taylor, P. D. \& Gordon, D. P. (2003). Endemic new cyclostome bryozoans from Spirits Bay, a New Zealand marine-biodiversity "hotspot". New Zealand Journal of Marine and Freshwater Research, 37, 653-669.

Taylor, P. D. \& McKinney, F. K. (2006). Cretaceous Bryozoa from the Campanian and Maastrichtian of the Atlantic and Gulf Coastal Plains, United States. Scripta Geologica, 132, 1-346.

Taylor, P. D., Gordon, D. P. \& Batson, P. B. (2004). Bathymetric distributions of modern populations of some common Cenozoic Bryozoa from New Zealand, and paleodepth estimation. New Zealand Journal of Geology and Geophysics, 47, 57-69. 
Taylor, P. D., Kuklinski, P. \& Gordon, D. P. (2007). Branch diameter and depositional depth in cyclostome bryozoans: testing a potential paleobathymetric tool. Palaios, 22, 220-224.

Taylor, P. D. \& Weedon, M. J. (2000). Skeletal ultrastructure and phylogeny of cyclostome bryozoans. Zoological Journal of the Linnean Society, 128, 337399.

Taylor, P. D., Waeschenbach, A. \& Florence, W. (2011). Phylogenetic position and systematics of the bryozoan Tennysonia: further evidence for convergence and plasticity in skeletal morphology among cyclostome bryozoans. Zootaxa, 3010, 58-68.

Taylor, P. D., Lombardi, C. \& Cocito, S. (2014). Biomineralization in bryozoans: present, past and future. Biological Reviews, DOI 10.1111/brv.12148.

Viskova, L. V. (1992). Morskie Postpaleozoyskie Mshanki. Trudy Paleontologicheskogo Instituta. Akademiya Nauk SSSR, Moscow, 250, 1-187. Waeschenbach, A., Cox, C. C., Littlewood, D. T. J., Porter, J. S. \& Taylor, P. D. (2009). First molecular estimate of cyclostome bryozoan phylogeny confirms extensive homoplasy among skeletal characters used in traditional taxonomy. Molecular Phylogenetics and Evolution, 52, 241-251.

Waeschenbach, A., Taylor, P. D. \& Littlewood, D. T. J. (2012). A molecular phylogeny of bryozoans. Molecular Phylogenetics and Evolution, 62, 718-735.

Walter, B. (1970). Les Bryozoaires Jurassiques en France. Documents des Laboratoires de Géologie de la Faculté des Sciences de Lyon, 35, 1-328.

Weedon, M. J. (1998). Skeletal ultrastructure of the early astogenetic stages of some cyclostome bryozoans. Acta Zoologica, 79, 163-174.

Weedon, M. J. \& Taylor, P. D. (1996). Skeletal ultrastructures in some cerioporine cyclostome bryozoans. Acta Zoologica, 77, 249-265.

Whitten, R. F. (1979). Systematics and ecology of northern Hauraki Gulf Bryozoa (Unpublished doctoral thesis). University of Auckland, Auckland, New Zealand. 


\section{Figure captions}

Figures 1, 2. Dried colonies of two cyclostome bryozoans from New Zealand described here. 1. Diaperoecia purpurascens (Hutton), unknown locality in New Zealand, NHMUK 2010.6.25.2. 2. 'Heteropora' neozelanica Busk, Otago Shelf, NHMUK 2014.12.17.1. Scale bars: $10 \mathrm{~mm}$.

Figures 3-8. Diaperoecia intricaria (Busk); back-scattered scanning electron micrographs of syntypes of the type species of the genus Diaperoecia; NHMUK 75.5.29.35, syntypes, SW Australia, Busk ex Gould Collection. 3. Bifurcating branches and kenozooidal flange (arrow). 4. Detail showing irregular distribution of autozooid apertures and a kenozooidal outgrowth (lower right). 5. Terminal diaphragm. 6. Autozooids with short peristomes and pseudoporous frontal walls. 7. Oblique transversely fractured branch. 8. Mural spine. Scale bars: $3,4=1 \mathrm{~mm}$; 5-7 = $100 \mu \mathrm{m} ; 8=10 \mu \mathrm{m}$.

Figures 9-18. Diaperoecia purpurascens (Hutton); back-scattered scanning electron micrographs. 9-12, 16. East Ulva Island, Paterson Inlet, Stewart Island, New Zealand, D. Foster and A. M. Smith Collection, 8/6/1995, NHMUK 2014.12.17.2; 9.

Bifurcating branch; 10. Detail showing autozooids; 11. Pseudopores across a zooidal boundary; 12. Transversely fractured branch; 16. Longitudinally sectioned branch showing aperture (upper left), distantly spaced interzooidal pores in interior walls, closely spaced pseudopores in exterior frontal wall (left), and mural spines growing from frontal wall. 13-15. From craypot at Waitangi, Chatham Island, P. D. Taylor Collection, 4/11/1999; 13, 14. NHMUK 2017.12.17.3; 13. Fertile branch showing longitudinally elongate gonozooid. 14. Detail of gonozooid and ooeciopore. 15. NHMUK 2017.12.17.4, another fertile branch with gonozooid scarcely visible (possible ooeciopore arrowed). 17, 18. Molecular sequence voucher specimen, Otago Shelf, A. M. Smith Collection, 25/1/2012, NHMUK 2017.12.17.5; 17. Broken branch; 18. Incomplete terminal diaphragm. Scale bars: $9,13,15=1 \mathrm{~mm} ; 10=200 \mu \mathrm{m} ; 11=$ $50 \mu \mathrm{m} ; 12,17=500 \mu \mathrm{m} ; 14,16,18=100 \mu \mathrm{m}$.

Figures 19, 20. Diaperoecia purpurascens (Hutton); back-scattered scanning electron micrographs of encrusting colony bases with broken ends of erect stems; arrows point 
to ancestrular protoecia. 19. Outside Whangaroa Harbour, 26/1/1981, National Museum of New Zealand BS 862. 20. Pleistocene fossil, Nukumaru Brown Sand, Nukumaru Beach, 01/2014, NHMUK BZ 7733, P. D. Taylor Collection. Scale bars = $1 \mathrm{~mm}$.

Figures 21-26. 'Hastingsia' whitteni sp. nov.; back-scattered scanning electron micrographs. 21, 22, 25, 26. Paratypes (molecular voucher specimens AW757), NZOI

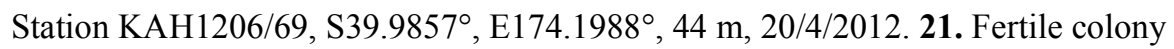
(possible ooeciopore arrowed) with ancestrula (bottom), paratype, NHMUK 2017.12.17.6. 22, 25. Paratype, NHMUK 2017.12.17.7; 22. Mural spine; 25. Entire colony showing ancestrula (left) with long peristome. 26. Paratype, semi-erect colony, NHMUK 2017.12.17.8. 23, 24. Auckland, on Sargassum sinclairii, 3/1/1996, D. P. Gordon Collection; 23. Holotype, NIWA 98120; 24. Incomplete gonozooid from paratype, NIWA 98121. Scale bars: $21,23,25,26=1 \mathrm{~mm} ; 22=10 \mu \mathrm{m} ; 24=500 \mu \mathrm{m}$.

Figures 27-32. 'Heteropora' neozelanica Busk. 27. Reproduction of colony illustrated by Busk (1879, fig. 1). 28-32. Back-scattered scanning electron micrographs of Busk's syntypes. 28, 30, 31. Lectotype, NHMUK 99.7.1.4281; 28. Branch fragment; 30. Autozooid surrounded by slightly smaller and more polygonal kenozooids. 31. Mural spines visible in kenozooid aperture. 29, 32. Paralectotype, NHMUK 99.7.1.4280; 29. Transversely sectioned branch showing axial endozone surrounded by exozone with thick-walled zooids; $\mathbf{3 2}$. Aborally convex terminal basal diaphragm. Scale bars: $27=10 \mathrm{~mm} ; 28,29=1 \mathrm{~mm} ; 30=200 \mathrm{~mm} ; 31=100 \mu \mathrm{m} ; 32$ $=50 \mu \mathrm{m}$.

Figures 33-45. 'Heteropora' spp. from New Zealand. 33-34, 36-37, 39-45, ' $H$ '. neozelanica Busk; back-scattered scanning electron micrographs. 33, 36, 39-45. NHM 2014.12.17.1, Otago Shelf, Stn Mu88-29, 87-89 m, 11/5/1988, P. D. Taylor Collection; 33. Bifurcating branch $_{2}=3$ 36. Detail of apertures of varying size, lacking a clear distinction between autozooids and kenozooids; 39. Branch with free-walled zooids distally and fixed-walled proximally; 40. Detail of fixed-walled part of branch showing autozooids with peristomes (some containing terminal diaphragms) and kenozooids with terminal diaphragms well proximal of wall edges. 41. Transversely fractured branch showing endozone and exozone; 42. Gonozooid with ooeciopore 
arrowed (distal is to the left); 43. Broken gonozooid surrounded by band of fixedwalled zooids; 44. Close-up of fixed-walled zooids showing autozooids with peristomes, kenozooids with terminal diaphragms almost flush with the ends of the vertical walls (cf. Fig. 40), and a zooid of a fouling cheilostome (top); 45. Detail of exterior-walled peristome with pseudopore (arrowed) and base of interior wall calcification. 34, 35, 37, 38. Molecular voucher specimens; 35, 38. Heteropora.sp.., NHMUK 2017.12.17.10, voucher NZ064, The Snares, 94 m, A. M. Smith \& J. Porter

Collection, February 2008; this species was distinguished using molecular evidence but is morphologically almost identical to specimens shown here as ' $H$.' neozelanica;

35. Branch surface; 38. Raised autozooidal apertures surrounded by kenozooids. 34, 37. ' $H$ '. neozelanica Busk'Heteropora' sp., NHMUK 2017.12.17.9, voucher AW086, The Snares, 54 m; The Snares, A. M. Smith \& J. Porter Collection, February 2008; this species was distinguished using molecular evidence but is morphologically almost identical to specimens shown here as ' $H$.' neozelanica; $; 3$. Branch surface showing free-walled zooids; 37 . Autozooidal and kenozooidal apertures moderately well differentiated; Scale bars: 33-35, 39, 41, $43=1 \mathrm{~mm}$; 36-38, 40, $44=200 \mu \mathrm{m}$; $42=500 \mu \mathrm{m} ; 45=100 \mu \mathrm{m}$.

Figure 46. Bayesian analysis of the concatenated lsrDNA and ssrDNA dataset constructed using MrBayes version 3.2.1 under the GTR $+\mathrm{I}+\mathrm{G}$ model; 5,000,000 generations, 2,000,000 generations burn-in. All nodes with $<0.95$ posterior probability have been collapsed. The branch length scale bar indicates number of substitutions per site. Box indicates the clade forming the focus of the current study. Cyclostome suborders based on conventional morphological classifications are given on the right.

Figures 47-52. Mural spines; high-resolution back-scattered electron micrographs. 47-49. Diaperoecia purpurascens (Hutton), National Museum of New Zealand BS 862, outside Whangaroa Harbour; 47. Group of mural spines on inside of frontal wall; 48. Detail of barbed mural spine with flat head; 49. Mural spine on interior wall with spinelets directed proximally. 50-52. 'Heteropora' neozelanica Busk, NHMUK 2014.12.17.1, Otago Shelf, Stn Mu88-29; 50. Kenozooid containing numerous mural spines; 51. Bifid mural spine; 52. Mural spine with long shaft. Scale bars: $47,50=50$ $\mu \mathrm{m} ; 48,49,51,52=5 \mu \mathrm{m}$. 
Figures 53-61. Comparative morphology of ancestrulae; back-scattered scanning electron micrographs. 53-55. Diaperoecia purpurascens (Hutton), outside Whangaroa Harbour, 26/1/1981, National Museum of New Zealand BS 862; 53. Ancestrula; 54. Protoecium; 55. Protoecial pseudopores. 56-58. 'Hastingsia' whitteni sp. nov., Auckland, on Sargassum sinclairii, 3/1/1996, D. P. Gordon Collection, paratype NIWA 98121; 56. Ancestrula; 57. Protoecium; 58. Protoecial pseudopores. 59-61. 'Heteropora' neozelanica Busk, NZOI Stn Z9684, NIWA 98122; 59.

Ancestrula; 60. Protoecium; 61. Protoecial pseudopores. Scale bars: 53, 56, 59= 200 $\mu \mathrm{m} ; 54,57,60=100 \mu \mathrm{m} ; 55,58,61=20 \mu \mathrm{m}$.

Figure 62-63. Annectocyma major (Johnston, 1847), English Channel, 49॰19.9,N $3^{\circ} 22.4^{\prime} \mathrm{W}, 77 \mathrm{~m}, 3 / 2 / 1962.62$, ancestrula with aperture closed by a terminal diaphragm, and early budded zooids. 63, damaged protoecium showing countersunk pseudopores. Scale bars: $62=500 \mu \mathrm{m} ; 63=200 \mu \mathrm{m}$.

Figure 642. Simplified vertical sections through young colonies of Diaperoecia purpurascens and 'Heteropora' showing skeletal organization similarity during early astogenetic stages compared with its dissimilarity in later stages when erect growth develops (see text for full explanation). Solid black lines indicate calcified skeletal walls; dashed lines uncalcified outer body walls enclosing hypostegal coelom. Everted tentacle crowns of autozooids are shown diagrammatically; open apertures between the autozooids in 'Heteropora' are kenozooids. 


\section{Supplementary Material}

Supplementary Figure 1. Bayesian analysis of the 1srDNA dataset constructed using MrBayes version 3.2.1 under the GTR $+\mathrm{I}+\mathrm{G}$ model; 5,000,000 generations, 4,500,000 generations burn-in. The branch length scale bar indicates number of substitutions per site.

Supplementary Figure 2. Bayesian analysis of the ssrDNA dataset constructed using MrBayes version 3.2.1 under the GTR $+\mathrm{I}+\mathrm{G}$ model; 5,000,000 generations, 4,500,000 generations burn-in. The branch length scale bar indicates number of substitutions per site. 


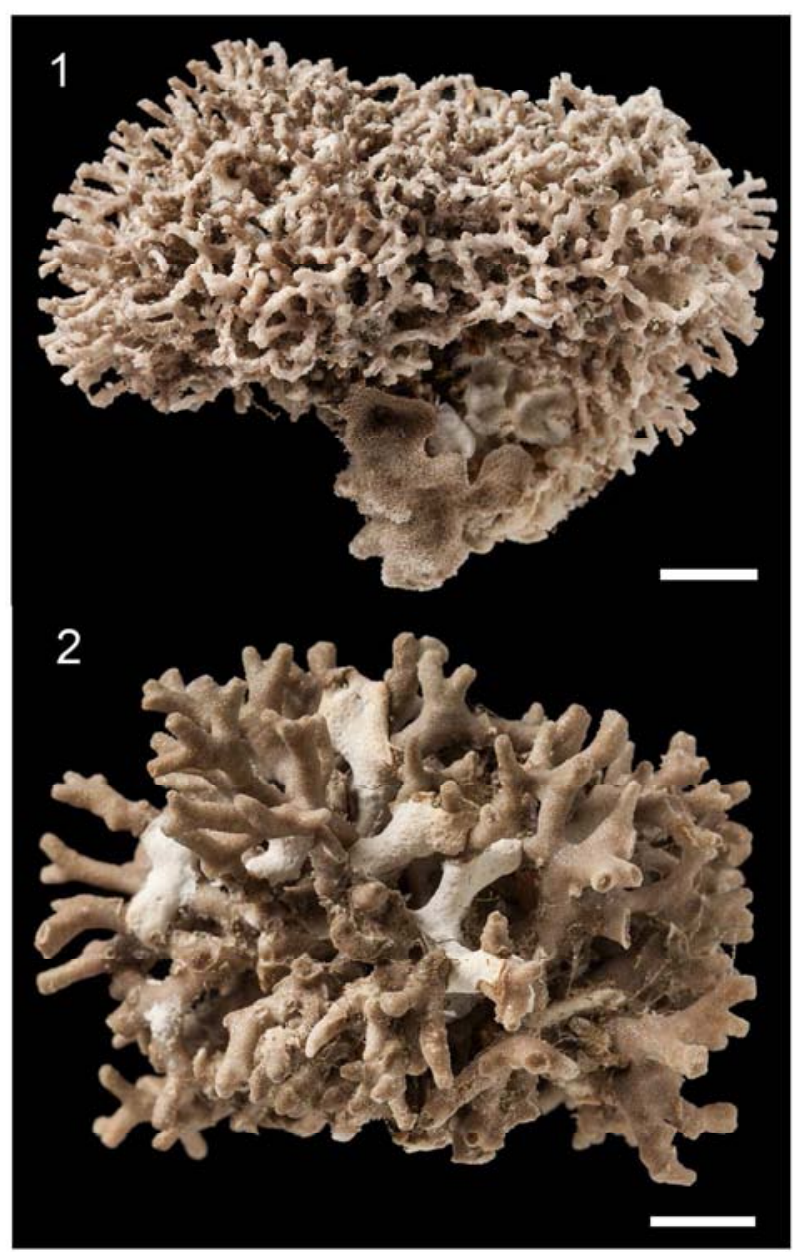

Figures 1, 2. Dried colonies of two cyclostome bryozoans from New Zealand described here. 1. Diaperoecia purpurascens (Hutton), unknown locality in New Zealand, NHMUK 2010.6.25.2. 2. 'Heteropora' neozelanica Busk, Otago Shelf, NHMUK 2014.12.17.1. Scale bars: $10 \mathrm{~mm}$. $99 \times 160 \mathrm{~mm}(300 \times 300$ DPI $)$ 


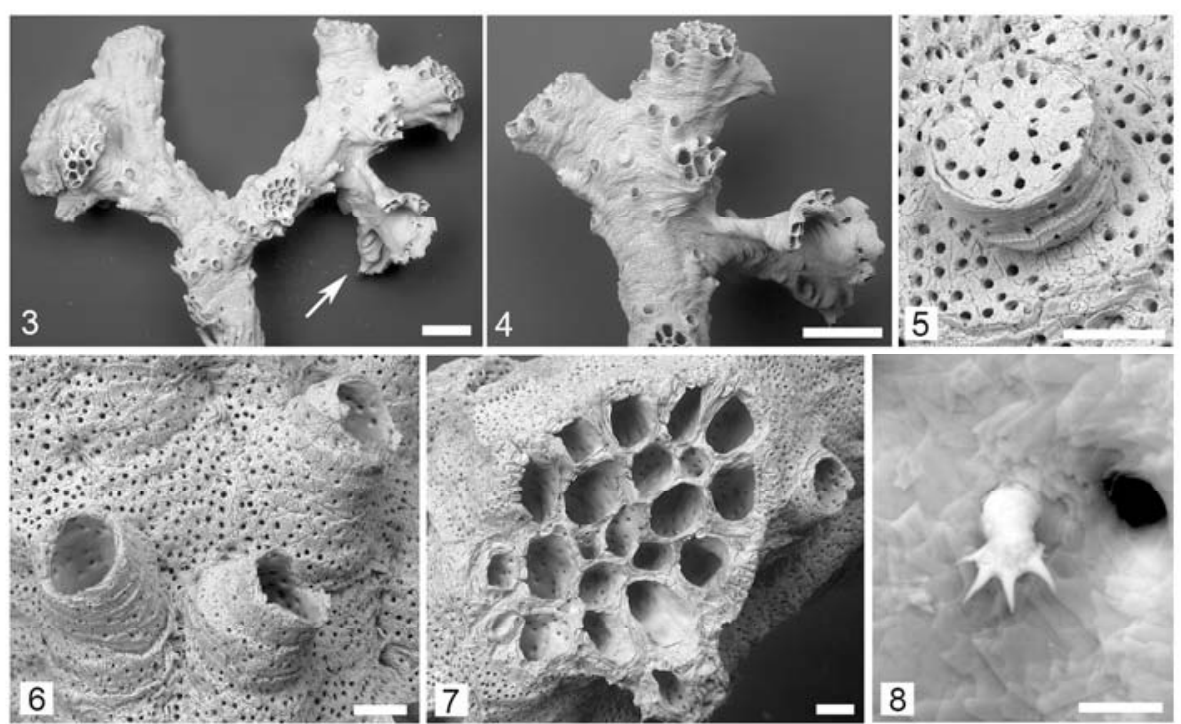

Figures 3-8. Diaperoecia intricaria (Busk); back-scattered scanning electron micrographs of syntypes of the type species of the genus Diaperoecia; NHMUK 75.5.29.35, syntypes, SW Australia, Busk ex Gould Collection. 3. Bifurcating branches and kenozooidal flange (arrow). 4. Detail showing irregular distribution of autozooid apertures and a kenozooidal outgrowth (lower right). 5. Terminal diaphragm. 6. Autozooids with short peristomes and pseudoporous frontal walls. 7. Oblique transversely fractured branch. 8. Mural spine. Scale bars: $3,4=1 \mathrm{~mm} ; 5-7=100 \mu \mathrm{m} ; 8=10 \mu \mathrm{m}$. $189 \times 140 \mathrm{~mm}(300 \times 300 \mathrm{DPI})$ 


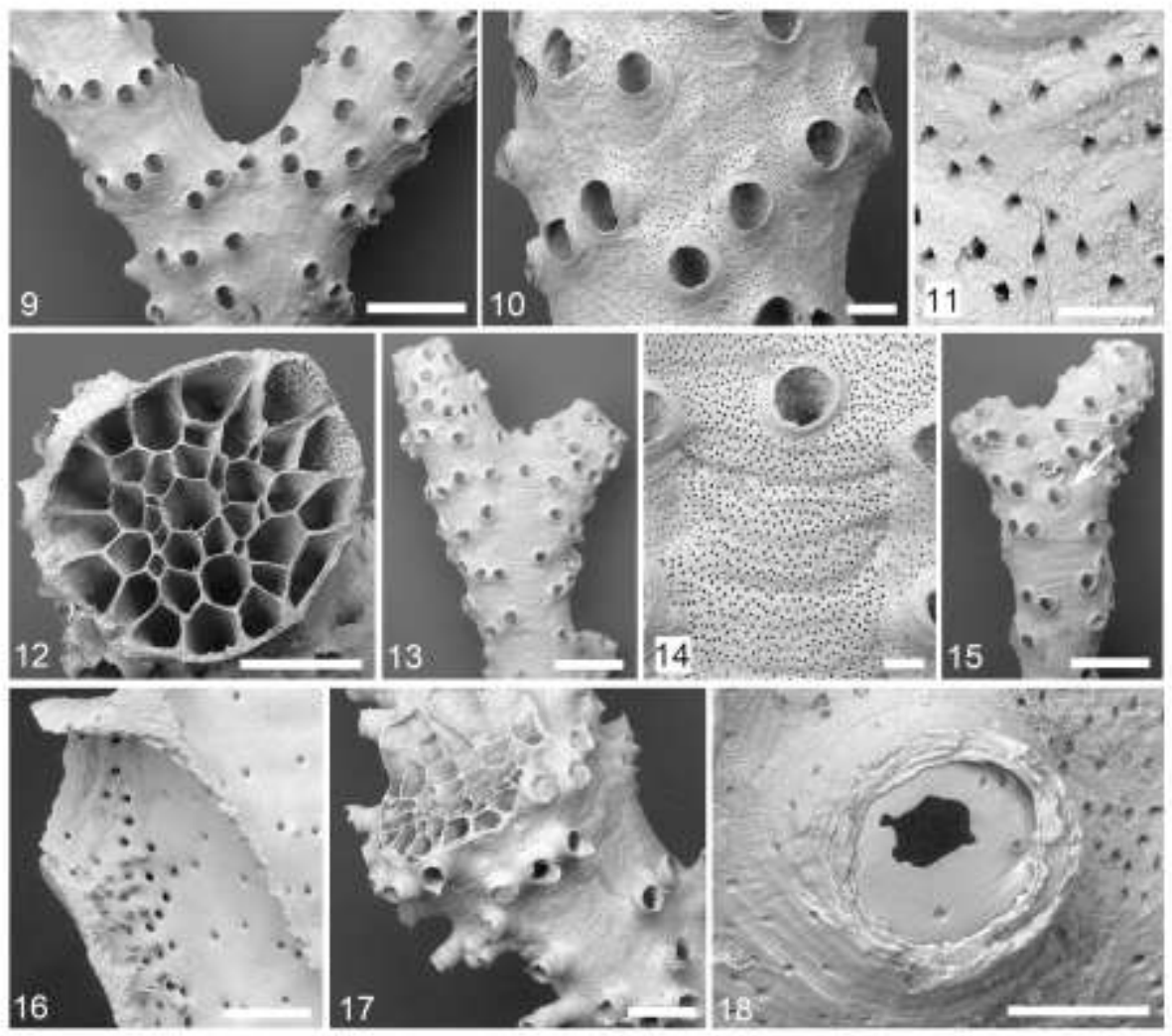

$189 \times 189 \mathrm{~mm}(300 \times 300 \mathrm{DPI})$ 

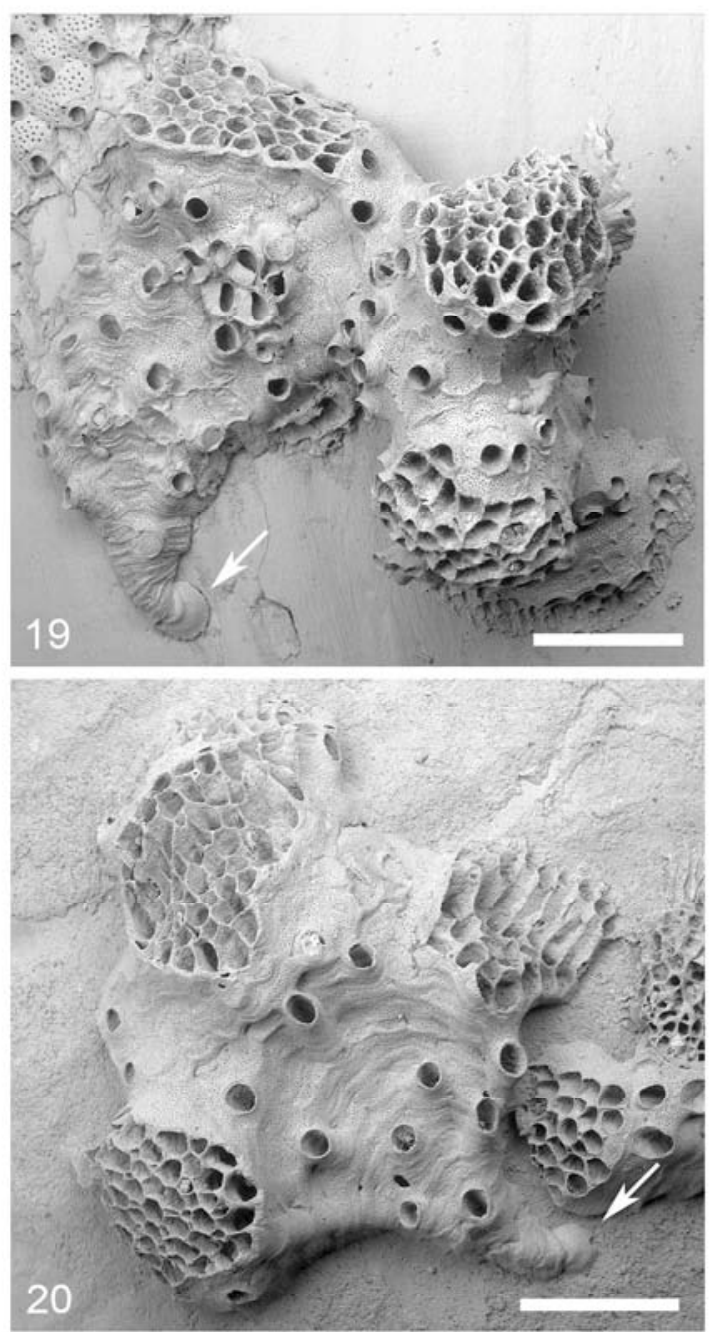

Figures 19, 20. Diaperoecia purpurascens (Hutton); back-scattered scanning electron micrographs of encrusting colony bases with broken ends of erect stems; arrows point to ancestrular protoecia. 19. Outside Whangaroa Harbour, 26/1/1981, National Museum of New Zealand BS 862. 20. Pleistocene fossil, Nukumaru Brown Sand, Nukumaru Beach, 01/2014, NHMUK BZ 7733, P. D. Taylor Collection. Scale bars $=1 \mathrm{~mm}$. $99 \times 180 \mathrm{~mm}(300 \times 300 \mathrm{DPI})$ 


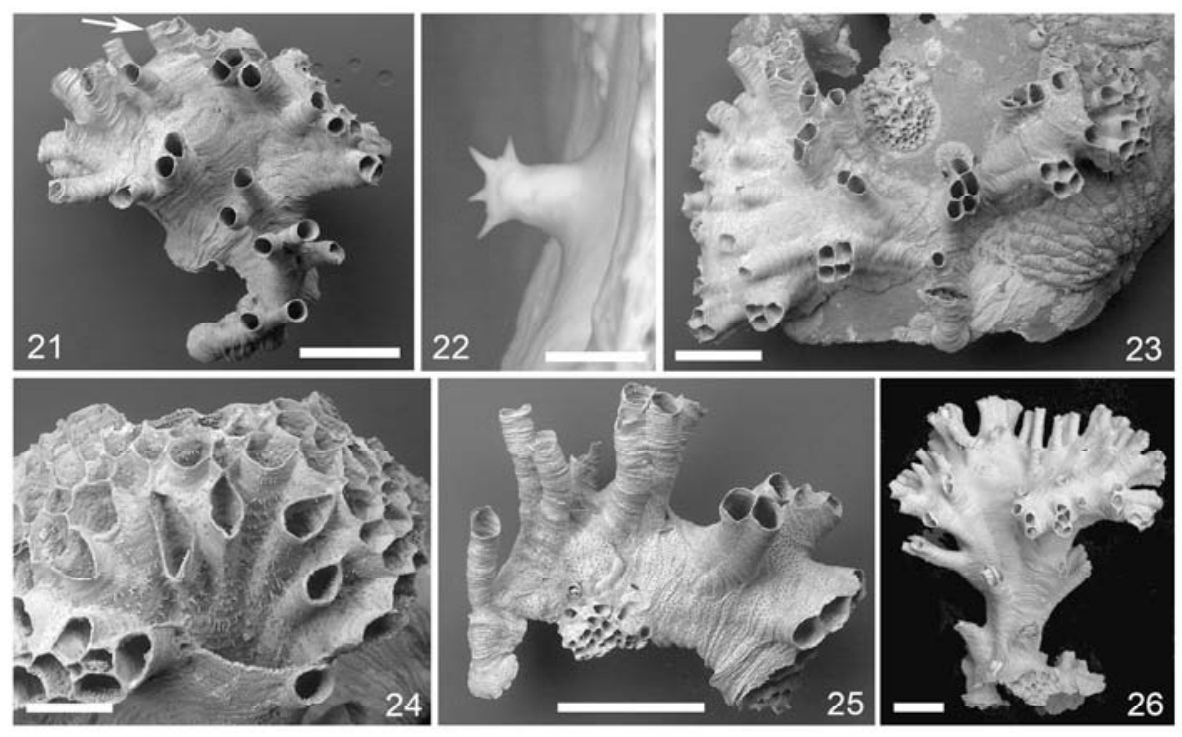

$189 \times 129 \mathrm{~mm}(300 \times 300$ DPI $)$ 

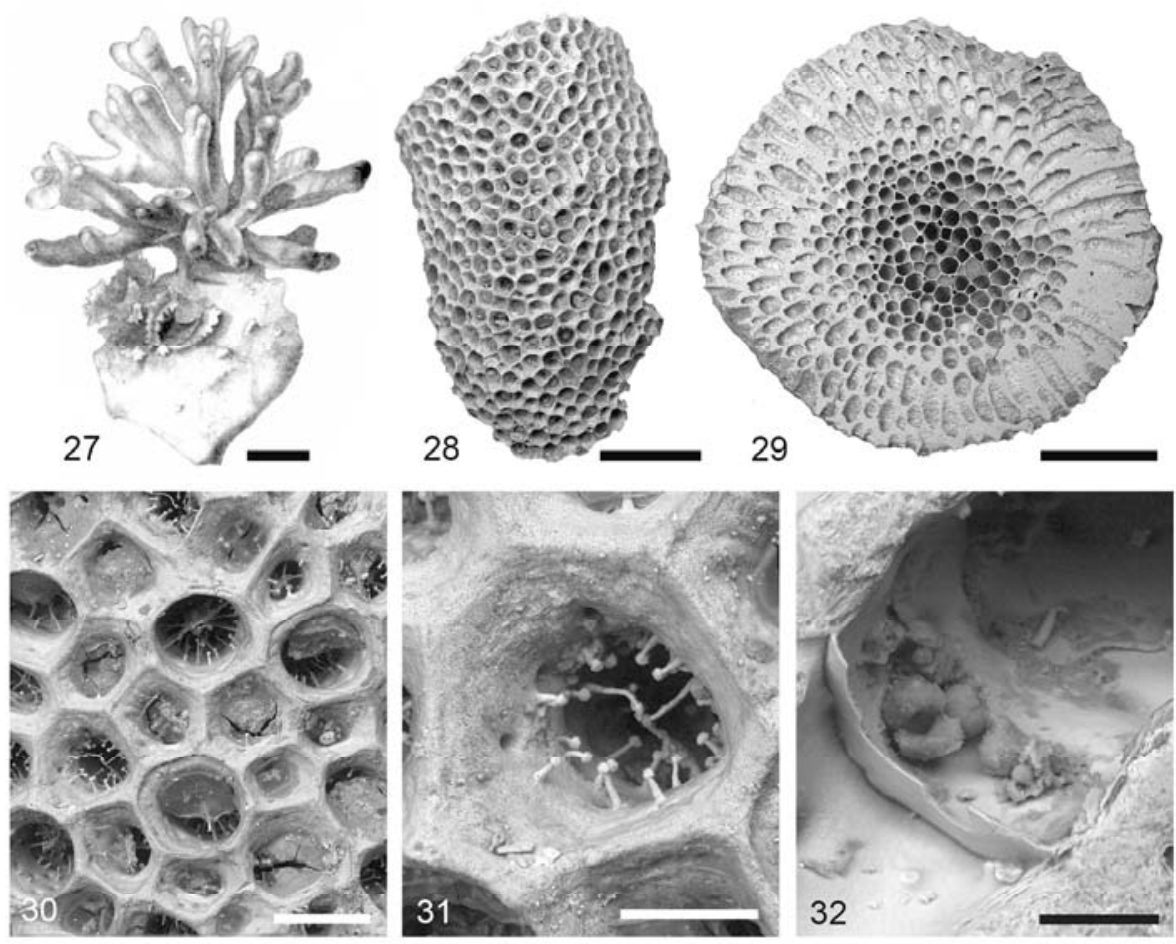

Figures 27-32. 'Heteropora' neozelanica Busk. 27. Reproduction of colony illustrated by Busk (1879, fig. 1). 28-32. Back-scattered scanning electron micrographs of Busk's syntypes. 28, 30, 31. Lectotype, NHMUK 99.7.1.4281; 28. Branch fragment; 30 . Autozooid surrounded by slightly smaller and more polygonal kenozooids. 31. Mural spines visible in kenozooid aperture. 29, 32. Paralectotype, NHMUK 99.7.1.4280; 29. Transversely sectioned branch showing axial endozone surrounded by exozone with thick-walled zooids; 32. Aborally convex terminal diaphragm. Scale bars: $27=10 \mathrm{~mm} ; 28,29=1 \mathrm{~mm} ; 30=200 \mathrm{~mm} ; 31=100$ $\mu \mathrm{m} ; 32=50 \mu \mathrm{m}$. $189 \times 180 \mathrm{~mm}(300 \times 300$ DPI $)$ 


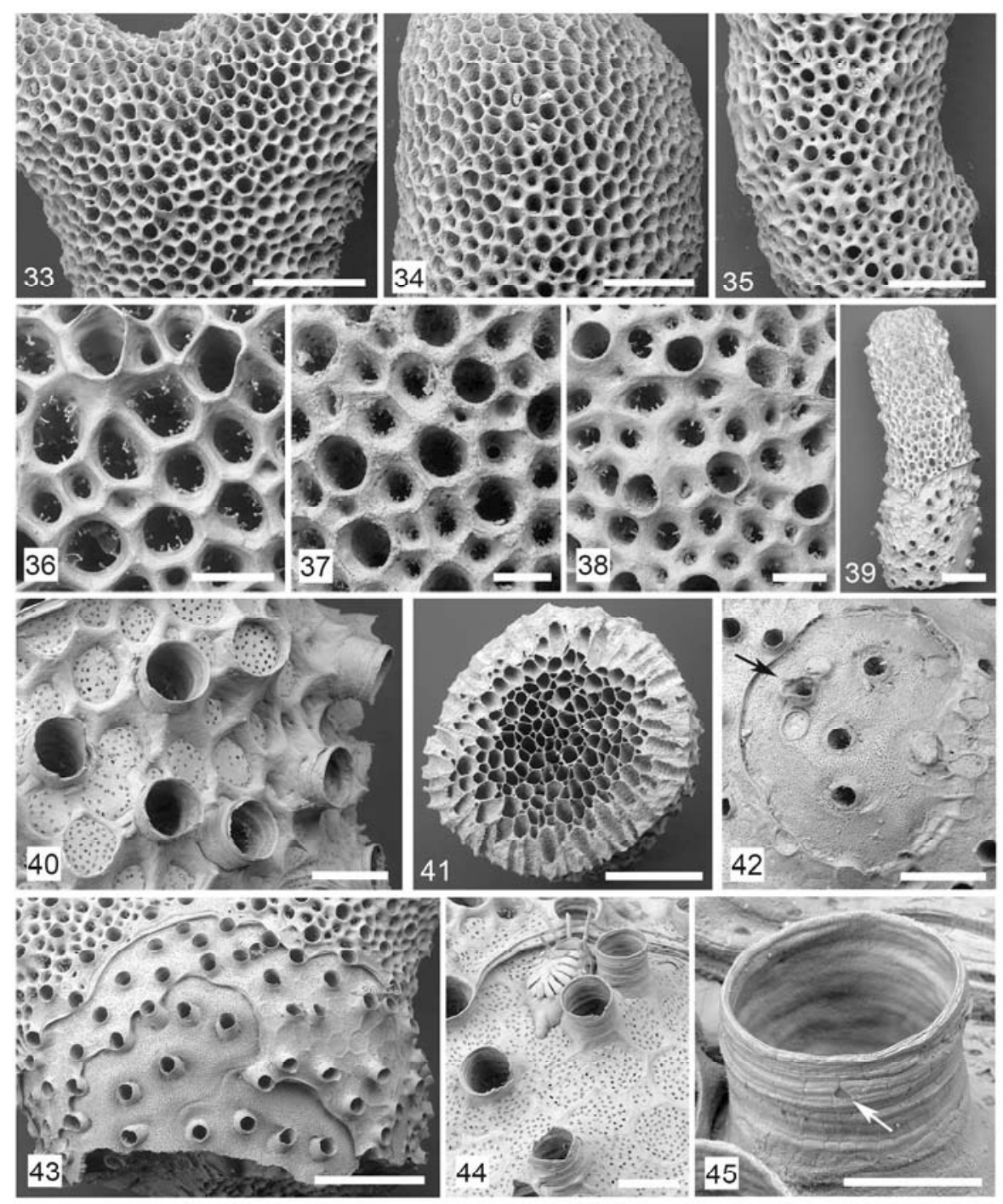

Figures 33-45. 'Heteropora' spp. from New Zealand. 33-34, 36-37, 39-45, ' $\mathrm{H}$ '. neozelanica Busk; backscattered scanning electron micrographs. 33, 36, 39-45. NHM 2014.12.17.1, Otago Shelf, Stn Mu88-29, 8789 m, 11/5/1988, P. D. Taylor Collection; 33. Bifurcating branch. 36. Detail of apertures of varying size, lacking a clear distinction between autozooids and kenozooids; 39 . Branch with free-walled zooids distally and fixed-walled proximally; 40 . Detail of fixed-walled part of branch showing autozooids with peristomes

(some containing terminal diaphragms) and kenozooids with terminal diaphragms well proximal of wall edges. 41. Transversely fractured branch showing endozone and exozone; 42. Gonozooid with ooeciopore arrowed (distal is to the left); 43. Broken gonozooid surrounded by band of fixed-walled zooids; 44 . Closeup of fixed-walled zooids showing autozooids with peristomes, kenozooids with terminal diaphragms almost flush with the ends of the vertical walls (cf. Fig. 40), and a zooid of a fouling cheilostome (top); 45. Detail of exterior-walled peristome with pseudopore (arrowed) and base of interior wall calcification. 34, 35, 37, 38. Molecular voucher specimens; 35, 38. NHMUK 2017.12.17.10, voucher NZ064, The Snares, 94 m, A. M. Smith \& J. Porter Collection, February 2008; 35. Branch surface; 38. Raised autozooidal apertures 
surrounded by kenozooids. 34, 37. 'Heteropora' sp., NHMUK 2017.12.17.9, voucher AW086, The Snares, 54 m; The Snares, A. M. Smith \& J. Porter Collection, February 2008; this species was distinguished using molecular evidence but is morphologically almost identical to specimens shown here as 'H.' neozelanica; 34. Branch surface showing free-walled zooids; 37. Autozooidal and kenozooidal apertures moderately well differentiated; Scale bars: 33-35, 39, 41, $43=1 \mathrm{~mm} ; 36-38,40,44=200 \mu \mathrm{m} ; 42=500 \mu \mathrm{m} ; 45=100$ $\mu \mathrm{m}$.

$189 \times 230 \mathrm{~mm}(300 \times 300 \mathrm{DPI})$ 

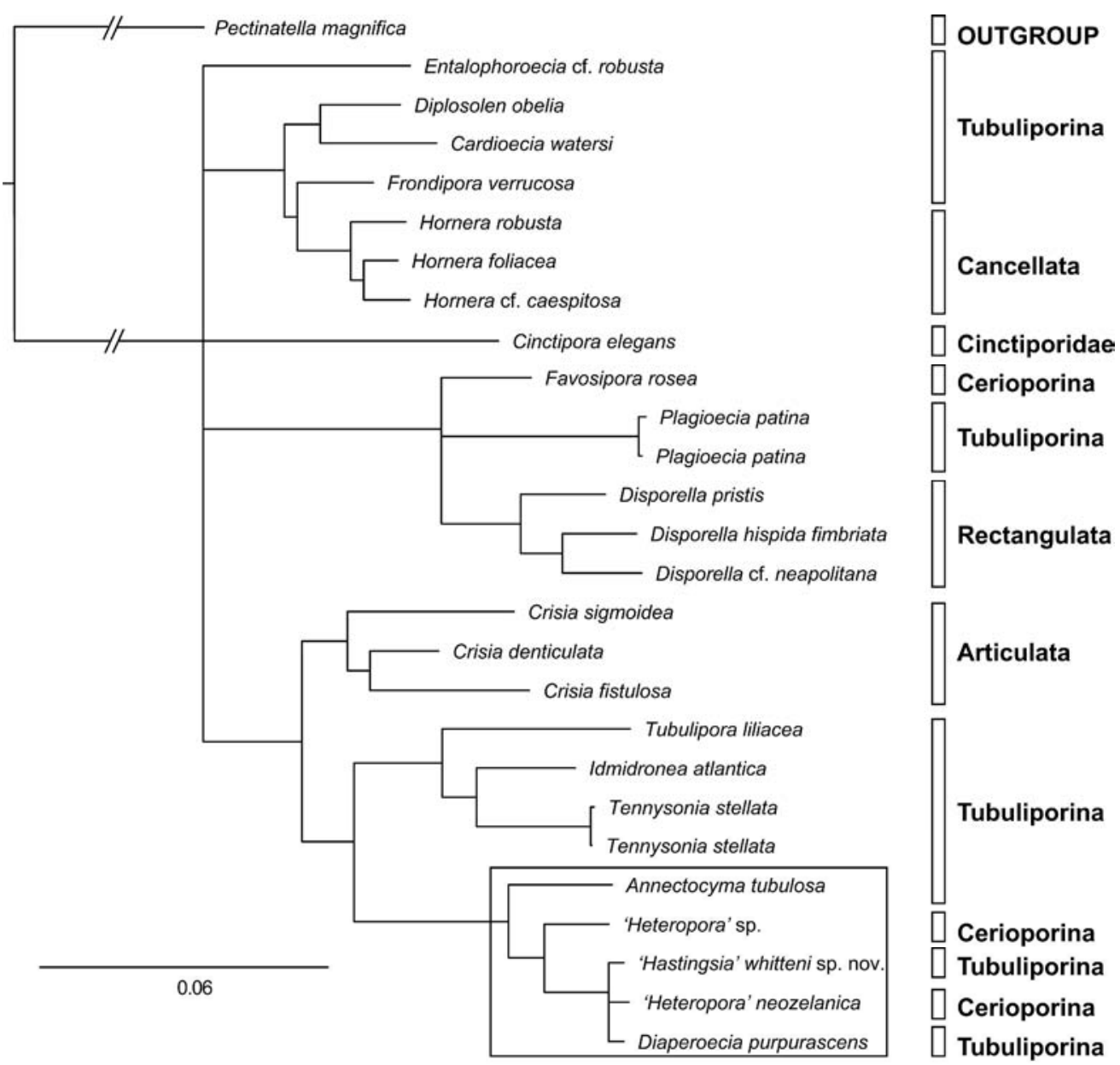

Figure 46. Bayesian analysis of the concatenated IsrDNA and ssrDNA dataset constructed using MrBayes version 3.2.1 under the GTR+I+G model; 5,000,000 generations, 2,000,000 generations burn-in. All nodes with $<0.95$ posterior probability have been collapsed. The branch length scale bar indicates number of substitutions per site. Box indicates the clade forming the focus of the current study. Cyclostome suborders based on conventional morphological classifications are given on the right. $450 \times 425 \mathrm{~mm}(300 \times 300$ DPI) 

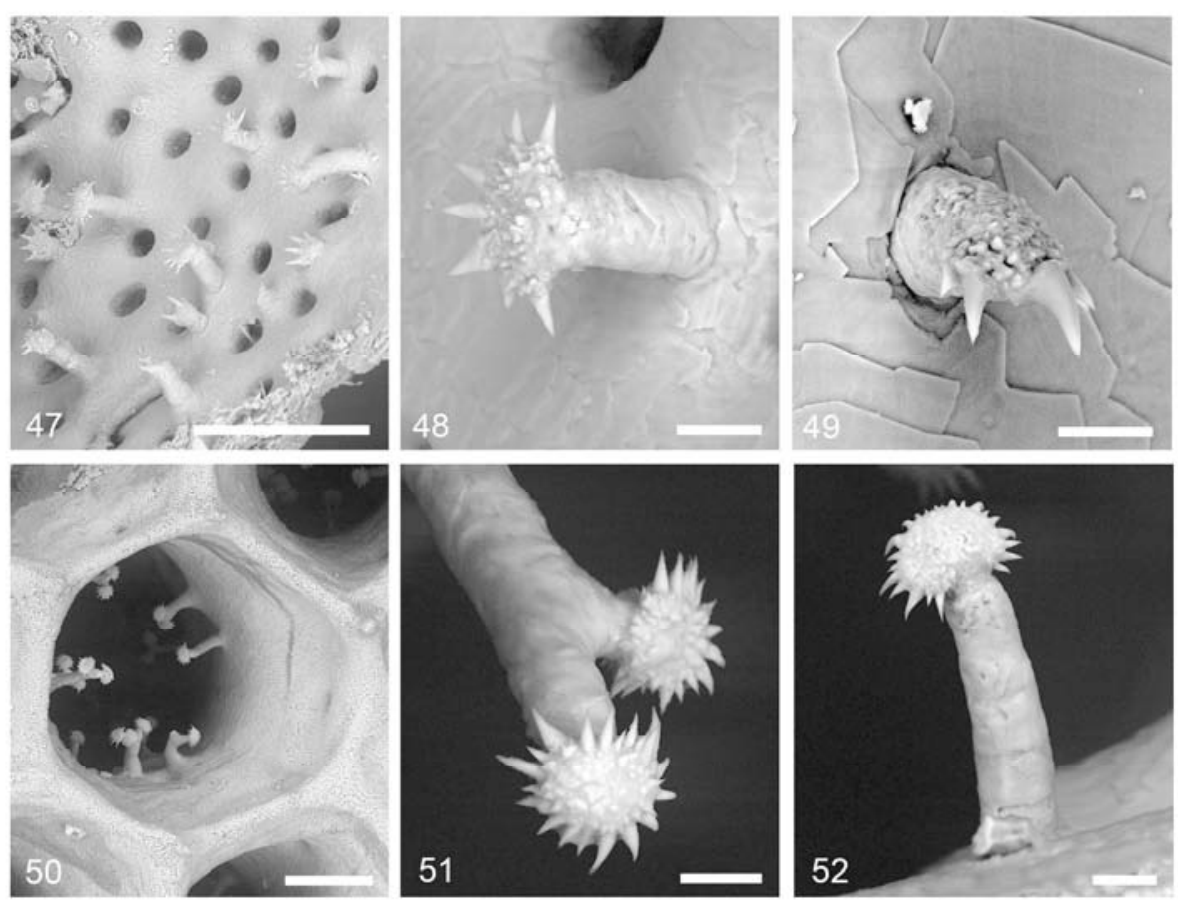

Figures 47-52. Mural spines; high-resolution back-scattered electron micrographs. 47-49. Diaperoecia purpurascens (Hutton), National Museum of New Zealand BS 862, outside Whangaroa Harbour; 47. Group of mural spines on inside of frontal wall; 48. Detail of barbed mural spine with flat head; 49. Mural spine on interior wall with spinelets directed proximally. 50-52. 'Heteropora' neozelanica Busk, NHMUK 2014.12.17.1, Otago Shelf, Stn Mu88-29; 50. Kenozooid containing numerous mural spines; 51. Bifid mural spine; 52. Mural spine with long shaft. Scale bars: $47,50=50 \mu \mathrm{m} ; 48,49,51,52=5 \mu \mathrm{m}$. $189 \times 180 \mathrm{~mm}(300 \times 300 \mathrm{DPI})$ 
Figures 53-61. Comparative morphology of ancestrulae; back-scattered scanning electron micrographs. 5355. Diaperoecia purpurascens (Hutton), outside Whangaroa Harbour, 26/1/1981, National Museum of New Zealand BS 862; 53. Ancestrula; 54. Protoecium; 55. Protoecial pseudopores. 56-58. 'Hastingsia' whitteni sp. nov., Auckland, on Sargassum sinclairii, 3/1/1996, D. P. Gordon Collection, paratype NIWA $98121 ; 56$. Ancestrula; 57. Protoecium; 58. Protoecial pseudopores. 59-61. 'Heteropora' neozelanica Busk, NZOI Stn Z9684, NIWA 98122; 59. Ancestrula; 60. Protoecium; 61. Protoecial pseudopores. Scale bars: 53, 56, 59 = $200 \mu \mathrm{m} ; 54,57,60=100 \mu \mathrm{m} ; 55,58,61=20 \mu \mathrm{m}$ $189 \times 189 \mathrm{~mm}(300 \times 300 \mathrm{DPI})$ 

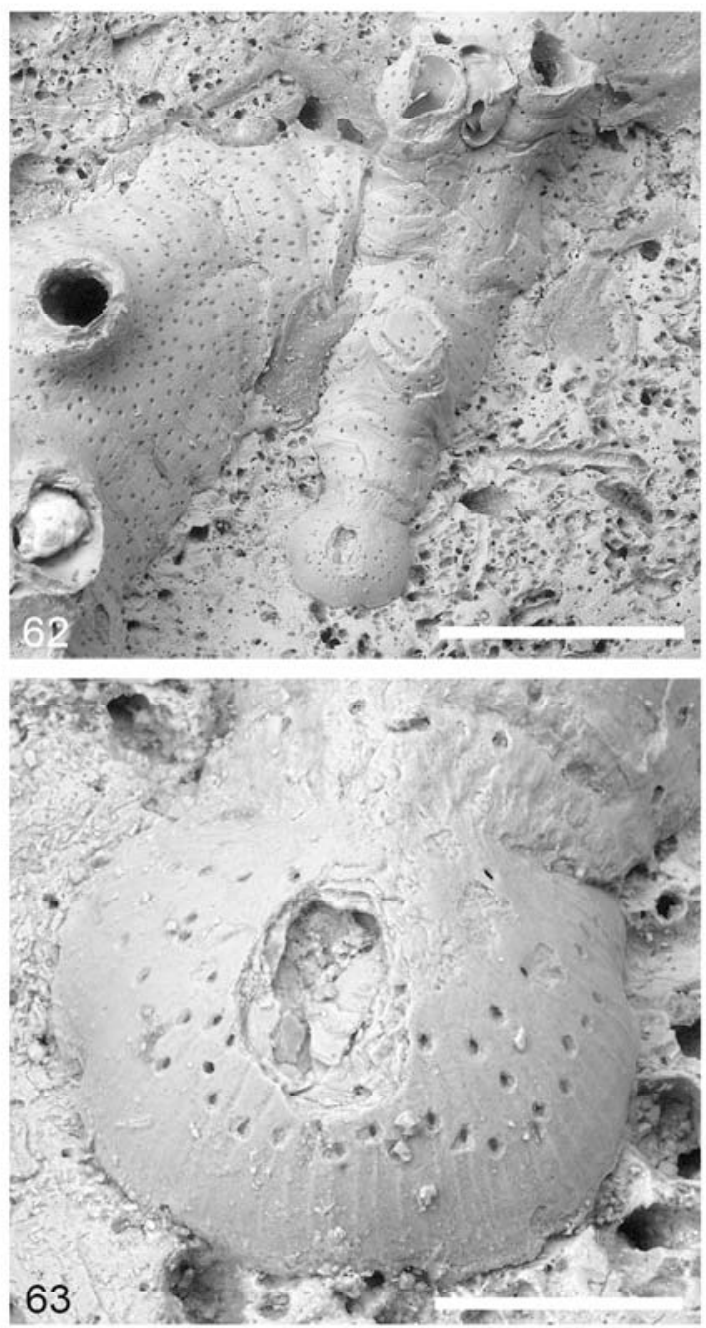

$99 \times 180 \mathrm{~mm}(300 \times 300 \mathrm{DPI})$ 
2

3

4

5

6
7

8
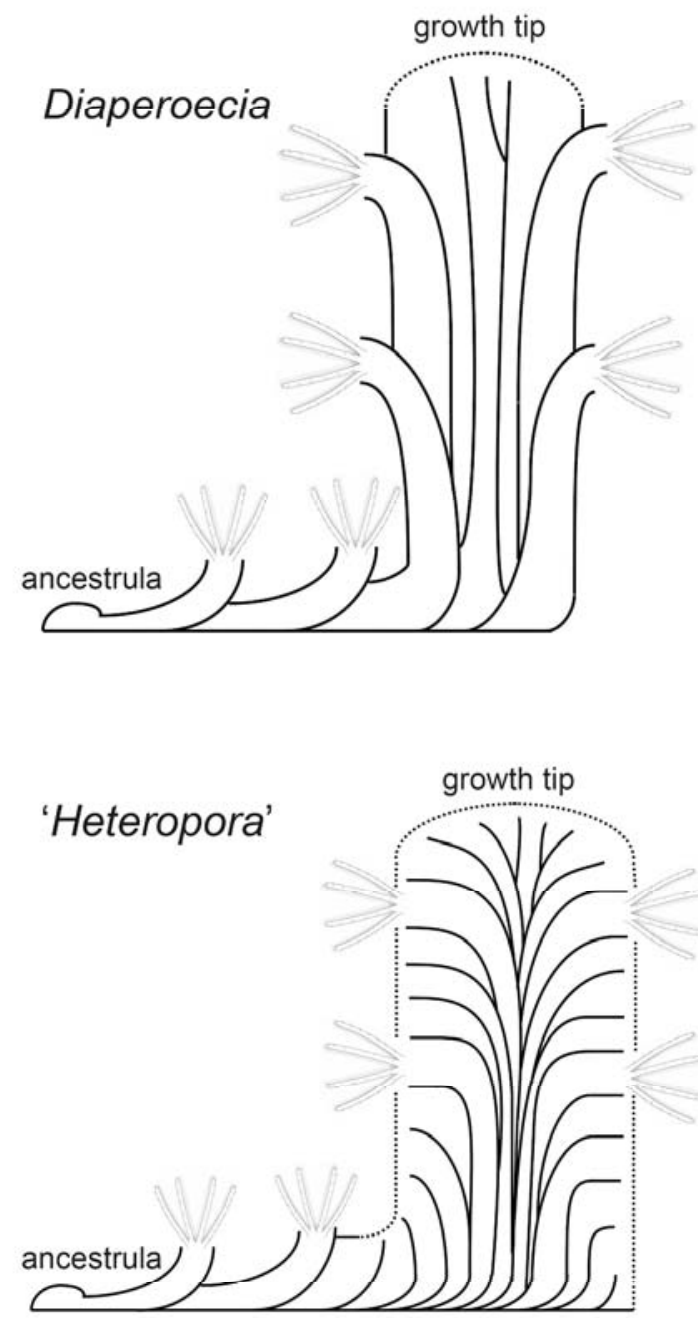

$180 \times 324 \mathrm{~mm}(300 \times 300 \mathrm{DPI})$ 
